\title{
Minerály kontaminovaných granitových pegmatitů z lomu Pohled u Havlíčkova Brodu (moldanubikum), část I: oxidy, karbonáty, silikáty a fosfáty
}

\author{
Minerals of contaminated granitic pegmatites from the Pohled quarry near Havlíčkův Brod \\ (Moldanubicum, Czech Republic), part I: oxides, carbonates, silicates and phosphates

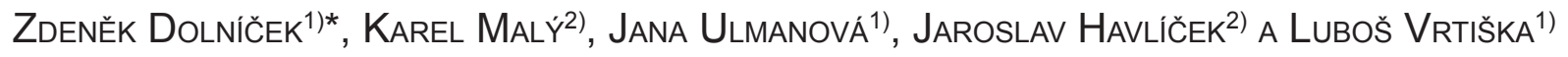 \\ 1)Mineralogicko-petrologické oddělení, Národní muzeum, Cirkusová 1740, 19300 Praha 9; \\ *e-mail: zdenek.dolnicek@nm.cz \\ 2)Muzeum Vysočiny Jihlava, Masarykovo náměstí 55, 58601 Jihlava
}

Dolniček Z, Malý K, Ulmanová J, HavličEK J, VRtišKa L (2020) Minerály kontaminovaných granitových pegmatitů z lomu Pohled u Havlíčkova Brodu (moldanubikum), část I: oxidy, karbonáty, silikáty a fosfáty. Bull Mineral Petrolog 28(1): 132-151 ISSN 2570-7337

\begin{abstract}
In the Pohled quarry near Havlíčkův Brod town (central part of the Czech Republic), granitic pegmatites form dikes or irregular bodies cementing breccia of host metamorphic rocks (paragneisses, amphibolites) belonging to the Monotonous (Ostrong) Group of the Moldanubicum of the Bohemian Massif. Pegmatites exhibit coarse-grained textures and very simple mineral composition, which, however, was in places strongly modified by superimposed hydrothermal alterations and locally also by crystallization of ore minerals. K-feldspar, plagioclase $\left(A n_{0-38}\right)$, biotite (phlogopite), apatite (fluorapatite to hydroxylapatite), zircon, allanite-(Ce) and part of quartz undoubtedly originated during the magmatic stage. Products of hydrothermal alterations include younger quartz, Fe-Mg chlorites (older clinochlore and younger chamosite with an admixture of Ca-smectite), prehnite, clinozoisite, amphibole (actinolite), titanite, calcite, and very probably also ilmenite (with up to $22.5 \mathrm{~mol}$. \% of pyrophanite), rutile, anatase and V-Cr-Fe-rich grossular with $13-25$ mol. \% of goldmanite and 12 - 24 mol. \% uvarovite. The elevated contents of $\mathrm{Mg}, \mathrm{Ca}, \mathrm{V}$ and $\mathrm{Cr}$ found in some minerals are associated with a material contamination by the surrounding metamorphic rocks (especially amphibolites, serpentinites and perhaps also graphitic lithologies), which took place with varying intensity during both magmatic and hydrothermal stages of evolution of the studied pegmatites. Geochemically, they are poorly fractionated pegmatites, whose origin was probably connected with anatexis of the host Moldanubian metamorphic rocks, which was likely associated with emplacement of adjacent small body of the Pohled Granodiorite.
\end{abstract}

Key words: contaminated granitic pegmatites, hydrothermal alteration, chlorite, allanite, V-Cr rich grossular, chemical composition, Moldanubicum, Bohemian Massif

Obdrženo 22. 3. 2020; prijiato 11. 5. 2020

Úvod

Lom Pohled u Přibyslavi (východně od Havlíčkova Brodu) představuje významnou mineralogickou lokalitu, jež byla v minulosti předmětem četných dílčích výzkumů. Pohledský lom je znám zejména výskytem polymetalického žilného Zn-Pb zrudnění typu k-pol (ve smyslu Bernarda 1981), jež regionálně spadá k havlíčkobrodskému rudnímu revíru. $Z$ těchto rudních žil byla popsána řada minerálů. Hlavními rudními minerály jsou sfalerit, pyrhotin, pyrit, méně arzenopyrit, galenit, chalkopyrit, akcesoricky i löllingit, markazit, tetraedrit, dyskrazit, kasiterit, stanin, pyrargyrit, gustavit, joséit A, joséit B, ryzí bismut a scheelit (Hak, Johan 1961; Dobeš, Malý 2001, Mastíková 2009, 2011; Kadlec 2018). Scheelit byl v nedávné době nalezen v polymetalické rudní žíle i ve sběratelsky atraktivních až $22 \mathrm{~mm}$ velkých žlutohnědých krystalech zarostlých do šedozeleného klinochloru (Kadlec 2018; Kopecký, Pauliš 2019). Žilovina rudních žil je tvořena křemenem, kalcitem, muskovitem a chloritem (Mastíková 2011). Ze supergenních minerálů byl na rudních žilách zjištěn mimetezit, devillin, linarit (jediný výskyt $v$ havlíčkobrodském rudním revíru), cerusit a akantit (Pauliš et al. 2012; Pauliš et al. 2013). Pozoruhodný byl nález krystalovaného vivianitu (Venclík et al. 2013) a také ojedinělého cronstedtitu (Hybler et al. 2016).

$\checkmark$ menší míře se $v$ lomu vyskytují $i$ další žilné hydrotermální mineralizace. Mastíková $(2009,2011)$ uvádí výskyty žil alpského typu (tvořených křemenem, kalcitem, chloritem, muskovitem, adulárem, titanitem, pyritem, pyrhotinem, akcesoricky molybdenitem, markazitem, scheelitem, allanitem a produkty jeho alterace - churchitem a rabdofánem); nověji jsou z nich popisovány i výskyty prehnitu, laumontitu a dalších zeolitů (Pauliš et al. 2015; Havlíček et al. 2018; Kadlec et al. 2018). Dále je z lomu uváděna př́tomnost žil tvořených křemenem (Hak, Johan 1961; Dobeš, Malý 2001; Mastíková 2011), dolomitem (Mastíková 2011), kalcitem (někdy s akcesorickou příměsí křemene, pyritu či fluoritu; Mastíková 2009, 2011) a žilek tvořených palygorskitem (Mastíková 2009).

Zajímavým fenoménem bylo vtroušeninové molybdenitové zrudnění, které tvořilo malé izolované hnízdo v žule 
(Moupic, Tošer 1985; Mastíková 2009; Seidlová 2011).

Welser a Záruba (2004) popsali z lomu Pohled čočkovitou pegmatitovou žílu směru ZJZ - VSV až JZ - SV o maximální mocnosti až $120 \mathrm{~cm}$, protínající okolní ruly a amfibolity. Autoři zdůrazňují texturní nehomogenitu pegmatitového tělesa. $V$ horní části odkryvu žíly rozlišili aplitickou, granitickou a blokovou jednotku, zatímco ve spodní části měla žíla spíše charakter aplitu s hnízdy hrubě zrnitého pegmatitu. Z tohoto pegmatitu Welser a Záruba (2004) uvádějí křemen, albit-oligoklas, mikroklin, biotit, fluorapatit, pyrit a amfibol. Přítomnost pyritu, biotitu a amfibolu podle autorů svědči o kontaminaci pegmatitu okolními amfibolity.

V souvislosti s plánovaným ukončením těžby kameniva $v$ lomu Pohled je na pořadu dne i brzký zánik této významné geologické a mineralogické lokality. Z toho důvodu jsme v roce 2019 v lomu odebrali reprezentativní dokladový mineralogický materiál pro sbírky Národního muzea $\vee$ Praze a Muzea Vysočiny $v$ Jihlavě a provedli i jeho základní mineralogické zhodnocení. $\mathrm{V}$ tomto příspěvku přinášíme nové poznatky k mineralogii pegmatitů, jimž, jak vyplývá z předchozích řádků, bylo až dosud věnováno ze strany mineralogů jen velmi málo pozornosti. Vzhledem $\mathrm{k}$ velkému množství nově získaných údajů je problematika rozdělena do dvou článků; $v$ této první části přinášíme nové údaje o minerálech ze skupiny oxidů, fosfátů, karbonátů a silikátů, zatímco předmětem zamýšlené druhé části by měly být poznatky o minerálech ze skupiny prvků, sulfidů a přibuzných sloučenin.

\section{Geologická pozice}

Pohledský lom se nachází asi 1200 m jv. od středu stejnojmenné obce a asi $500 \mathrm{~m}$ jjz. od obce Simtany. V lomu je odkryt kontakt mezi metamorfity severní části moravské větve jednotvárné (nověji ostrongské) skupiny moldanubika a tělesem tzv. pohledské žuly (obr. 1). Metamorfity moldanubika jsou v prostoru lomu reprezentovány zejména různě intenzivně migmatitizovanými biotitickými pararulami s až $10 \mathrm{~m}$ mocnými vložkami amfibolitů. $\checkmark$ rulách a migmatitech se místy objevují i drobné (max. desítky $\mathrm{cm}$ velké) ultramafické uzavřeniny, tvořené hornblenditem, pyroxenitem, eklogitem či serpentinizovaným dunitem (posledně jmenovaný typ je typicky vrouben antofylitovým lemem), jejichž bližší charakteristiku uvádějí Turek $(2006,2008)$ a Mastíková (2009).

Pohledská žula je bílošedá, slabě porfyrická, všesměrně zrnitá magmatická hornina, petrograficky odpovídající biotitickému granodioritu (Doleželová 2015). Těleso pohledské žuly pravděpodobně představuje apofýzu melechovského masivu (Beneš 1963). Radiometrické datování dosud nebylo provedeno, vzhledem k absenci usměrnění horniny jde však zjevně o posttektonickou intruzi. Kontakt s okolními metamorfity je intruzivní.

Metamorfované horniny jsou v lomu místy protínány drobnými žilami aplitů či pegmatitů. Nikdy nebyly pozorovány $v$ prostředí pohledského granodioritu. Aplity jsou bělavé až nažloutlé, jemně zrnité horniny složené z křemene a živců. Žily aplitů dosahuji řádově centimetrových až decimetrových mocností.

Pegmatity $v$ prostoru lomu tvoří jednak žíly diskordantní vůči foliaci okolních metamorfitů, jednak tmel pojící ostrohranné bloky brekciovaných hostitelských metamorfitů. Prvně zmiňovanou morfologickou formu popisuji Welser a Záruba (2004), druhý zmiňovaný typ výskytu byl často nalézán autory tohoto príspěvku $v$ posledních letech. Zatímco u žil výše citovaní autoři uvádějí přítomnost i několika texturně-paragenetických jednotek (aplitická, granitická, bloková), v námi dokumentovaných výskytech značně převažuje hrubě zrnitá textura pegmatitu $s$ velikostí zrn v prvních jednotkách $\mathrm{cm}$, která obvykle nevykazuje žádnou makroskopicky patrnou texturní zonalitu. Jen ojediněle byl zaznamenán při kontaktu s okolní horninou tenký lem (centimetrová mocnost) jemnozrnnější aplitické či granitické facie. $V$ centrálních částech pegmatitových výplní bývají někdy prítomna ostře ohraničená hnízda o velikosti až $30 \mathrm{~cm}$, tvořená hlavně amfibolem. Poměrně často jsou v pegmatitech přítomny mladší žilky a drobná hnízda sulfidů, z nichž je makroskopicky patrný zejména pyrit, méně i sfalerit.

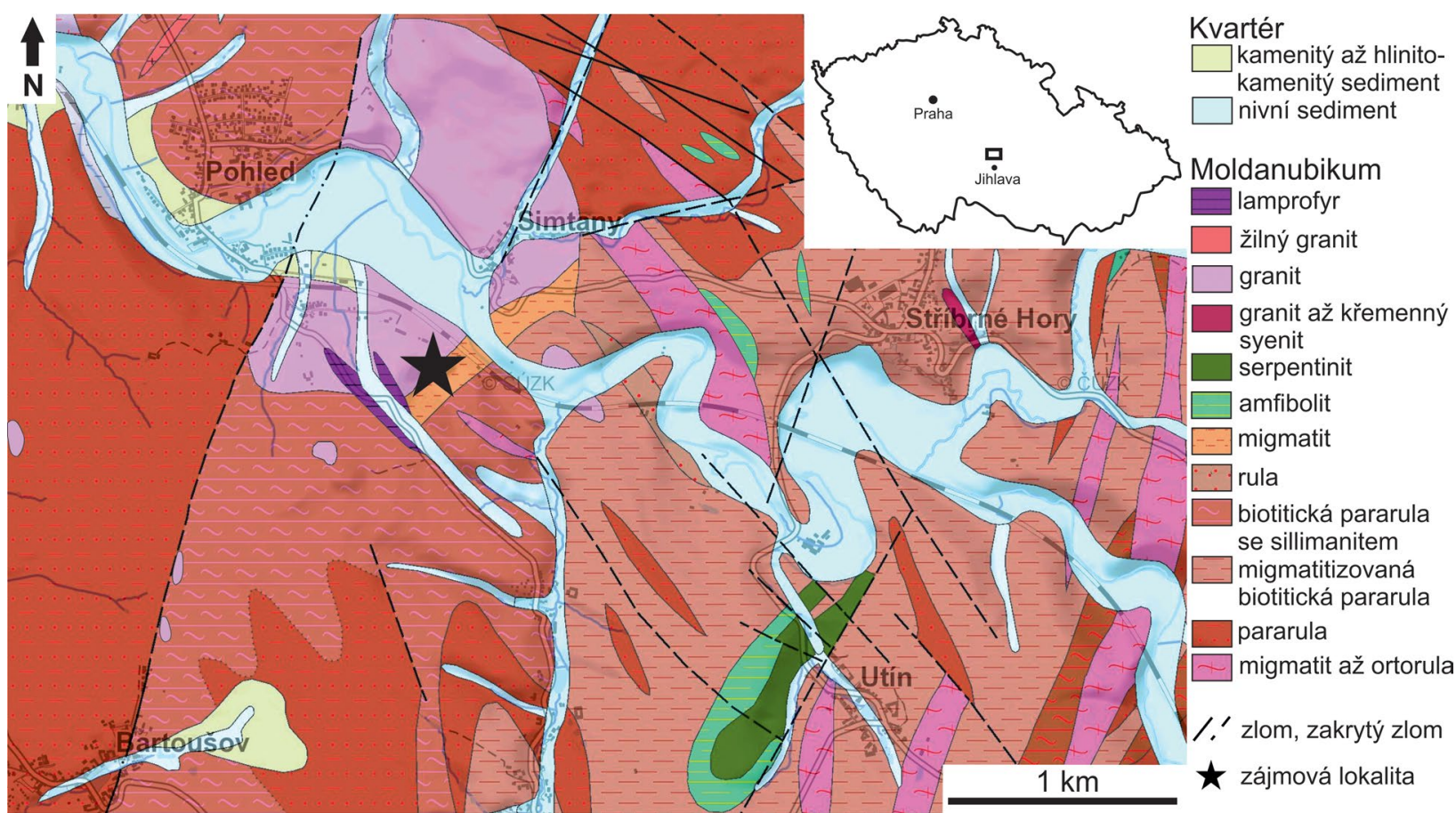

Obr. 1 Geologická pozice studované lokality. Podkladová mapa převzata a upravena z elektronické verze geologické mapy 1:50000 (www.geology.cz). 


\section{Materiál a metodika}

Všechny studované vzorky byly odebrány autory předložené studie $v$ průběhu roku 2019. Vzorky pocházely většinou z nejspodnější, aktuálně těžené etáže lomu a byly odebrány hlavně z rozvalu. Většina blíže studovaných vzorků představuje typický hrubě zrnitý pegmatit, $v$ některých prípadech na kontaktu s hnízdy amfibolu. Většina vzorků byla více nebo méně postižena mladšími hydrotermálními alteracemi, projevujícími se přítomností korozních dutin, sulfidů, karbonátů a chloritů. Makrofotografie vybraných fází byly zhotoveny pomocí mikroskopu Nikon SMZ 25 s digitální kamerou Nikon DS-Ri2 za použití funkce skládání obrazu v programu NIS Elements AR verze 4.20. Z reprezentativních vzorků byly následně diamantovou pilou vyřezány mineralogicky zajímavější partie a z nich byly zhotoveny (P. Sečkár, Univerzita Komenského, Bratislava) leštěné nábrusy a výbrusy. Dokumentace zhotovených preparátů v odraženém či pro-
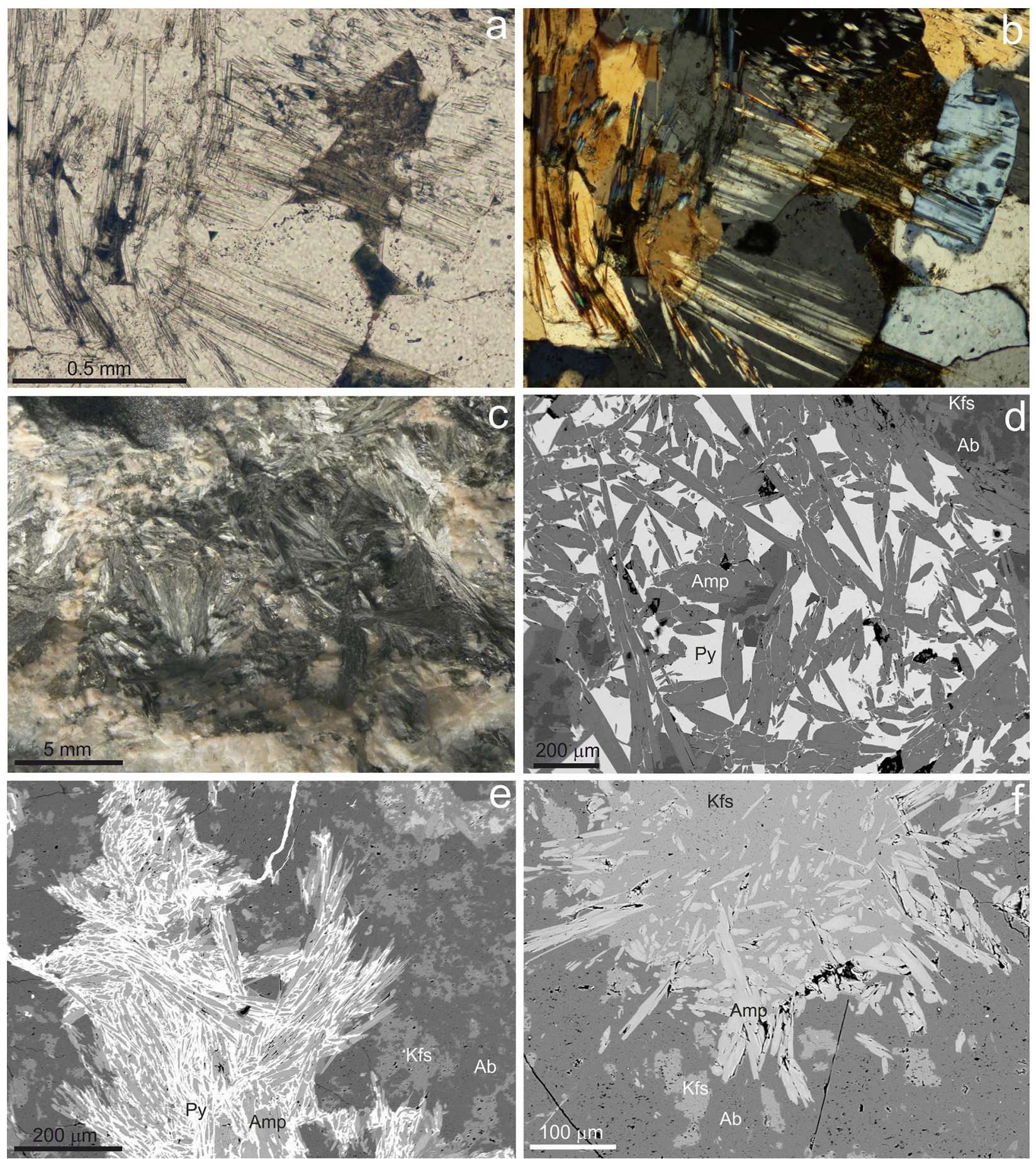

Obr. 2 Minerální asociace a vývin minerálů ze studovaných pegmatitů z lomu Pohled. a,b - mladší generace křemene, prorůstaná jehlicovitým aktinolitem a obklopovaná chloritem. Výbrus, procházející světlo, PPL (a), XPL (b); $c$ - radiálně paprsčité agregáty amfibolu z amfibolového hnízda $v$ asociaci se světle zbarveným plagioklasem; $d$ - automorfní individua amfibolu (Amp) obklopovaná pyritem (Py), K-živcem (Kfs) a albitem (Ab), BSE obraz; e - zatlačování amfibolu mladším pyritem, BSE obraz; $f$ - prorůstání jehlic amfibolu do okolních živců (Ab - albit, Kfs - K-živec), BSE obraz. Snímky J. Ulmanová a Z. Dolníček. 
cházejícím polarizovaném světle byla provedena na polarizačním mikroskopu Nikon Eclipse ME600 vybaveném digitální kamerou Nikon DXM1200F.

Následně byly nábrusy a výbrusy vakuově napařeny uhlíkovou vrstvou o tloušt'ce $30 \mathrm{~nm}$ a studovány na elektronové mikrosondě Cameca SX-100 (Národní muzeum, Praha). Na prístroji byly pořizeny snímky ve zpětně odražených elektronech (BSE), provedena identifikace jednotlivých fází pomocí energiově disperzních (EDS) spekter a kvantitativně měřeno chemické složení vybraných fází ve vinově disperzním (WDS) modu. Při kvantitativních analýzách kyslíkatých minerálů byly použity následující podmínky: urychlovací napětí $15 \mathrm{kV}$, proud svazku $20 \mathrm{nA}$ (allanit, minerály $\mathrm{TiO}_{2}$, ilmenit, titanit), respektive $10 \mathrm{nA}$ (všechny ostatní fáze) a průměr elektronového svazku mezi 0.7 a $3 \mu \mathrm{m}$. V živcích byly měřeny obsahy $\mathrm{Al}, \mathrm{Ba}$, $\mathrm{Ca}, \mathrm{Cs}, \mathrm{Cu}, \mathrm{F}, \mathrm{Fe}, \mathrm{Mg}, \mathrm{Mn}, \mathrm{N}, \mathrm{K}, \mathrm{Na}, \mathrm{P}, \mathrm{Pb}, \mathrm{Rb}, \mathrm{Si}, \mathrm{Sr}$ a $\mathrm{Zn}$, v amfibolech obsahy $\mathrm{Al}, \mathrm{Ba}, \mathrm{Ca}, \mathrm{Cl}, \mathrm{Cr}, \mathrm{F}, \mathrm{Fe}, \mathrm{K}, \mathrm{Mg}$, $\mathrm{Mn}, \mathrm{N}, \mathrm{Na}, \mathrm{Ni}, \mathrm{P}, \mathrm{Pb}, \mathrm{Si}, \mathrm{Sr}, \mathrm{Ti}, \mathrm{V}$ a $\mathrm{Zn}, \mathrm{v}$ titanitu obsahy $\mathrm{Al}, \mathrm{Ca}, \mathrm{Ce}, \mathrm{F}, \mathrm{Fe}, \mathrm{Hf}$, La, Mg, Na, Nb, Nd, Pb, Pr, Sc, Si, $\mathrm{Sn}, \mathrm{Ta}, \mathrm{Ti}, \mathrm{Y}$ a $\mathrm{Zr}$, v ilmenitu a $\mathrm{TiO}_{2}$ minerálech obsahy $\mathrm{Al}$, As, $\mathrm{Ca}, \mathrm{Cr}, \mathrm{Fe}, \mathrm{Mg}, \mathrm{Mn}, \mathrm{Mo}, \mathrm{Na}, \mathrm{Nb}, \mathrm{P}, \mathrm{Pb}, \mathrm{S}, \mathrm{Sc}, \mathrm{Si}, \mathrm{Sn}$, Ta, Ti, U, V, W, Y a Zr, v chloritech, klinozoisitu a prehnitu obsahy $\mathrm{Al}, \mathrm{Ba}, \mathrm{Ca}, \mathrm{Cl}, \mathrm{Co}, \mathrm{Cr}, \mathrm{Cs}, \mathrm{Cu}, \mathrm{F}, \mathrm{Fe}, \mathrm{K}, \mathrm{Mg}, \mathrm{Mn}$, $\mathrm{N}, \mathrm{Na}, \mathrm{Ni}, \mathrm{P}, \mathrm{Pb}, \mathrm{Rb}, \mathrm{Sb}, \mathrm{Si}, \mathrm{Ti}, \mathrm{V}$ a Zn, v zirkonu obsahy $\mathrm{Al}, \mathrm{As}, \mathrm{Ba}, \mathrm{Bi}, \mathrm{Ca}, \mathrm{Ce}, \mathrm{Cl}, \mathrm{Cu}, \mathrm{Dy}, \mathrm{Eu}, \mathrm{Er}, \mathrm{F}, \mathrm{Fe}, \mathrm{Gd}, \mathrm{Hf}$, $\mathrm{Ho}, \mathrm{K}, \mathrm{La}, \mathrm{Lu}, \mathrm{Mg}, \mathrm{Mn}, \mathrm{N}, \mathrm{Na}, \mathrm{Nd}, \mathrm{P}, \mathrm{Pb}, \mathrm{Pr}, \mathrm{S}, \mathrm{Sc}, \mathrm{Si}$, $\mathrm{Sm}, \mathrm{Sr}, \mathrm{Tb}, \mathrm{Th}, \mathrm{Ti}, \mathrm{Tm}, \mathrm{U}, \mathrm{V}, \mathrm{Y}, \mathrm{Yb}$ a $\mathrm{Zr}$ a v allanitech obsahy $\mathrm{Al}, \mathrm{As}, \mathrm{Ba}, \mathrm{Ca}, \mathrm{Ce}, \mathrm{Cl}, \mathrm{Cr}, \mathrm{Cu}, \mathrm{Eu}, \mathrm{F}, \mathrm{Fe}, \mathrm{Gd}, \mathrm{K}$, La, $\mathrm{Mg}, \mathrm{Mn}, \mathrm{Na}, \mathrm{Nd}, \mathrm{Ni}, \mathrm{P}, \mathrm{Pb}, \mathrm{Pr}, \mathrm{Si}, \mathrm{Sm}, \mathrm{Sr}, \mathrm{Th}, \mathrm{Ti}, \mathrm{U}, \mathrm{V}, \mathrm{Y}$, Zn a Zr. Při analýzách byly použity následující standardy a analytické čáry: albit $(\mathrm{NaK} \alpha)$, almandin (AlKa, $\mathrm{FeK} \alpha)$, antimonit $(\mathrm{Sb} L \alpha)$, apatit $(\mathrm{P} K \alpha)$, baryt $(\mathrm{Ba} L \alpha), \mathrm{Bi}(\mathrm{Bi} M \alpha)$, $\mathrm{BN}(\mathrm{N} K \alpha)$, celestin $(\mathrm{S} K \alpha, \mathrm{Sr} L \beta), \mathrm{CePO}_{4}(\mathrm{Ce} L \alpha), \mathrm{Cr}_{2} \mathrm{O}_{3}$ $(\mathrm{Cr} K \alpha), \mathrm{CrTa}_{2} \mathrm{O}_{6}(\mathrm{Ta} L \alpha)$, Cs-sklo $(\mathrm{Cs} L \alpha)$, diopsid $(\mathrm{MgK} \alpha)$,
$\mathrm{DyPO}_{4}(\mathrm{Dy} L \beta), \mathrm{ErPO}_{4}(\mathrm{ErL} \alpha), \mathrm{EuPO}_{4}(\mathrm{EuL} \alpha), \mathrm{GdPO}_{4}$ $(\mathrm{Gd} L \alpha)$, halit $(\mathrm{Cl} K \alpha)$, hematit $(\mathrm{Fe} K \alpha)$, $\mathrm{Hf}(\mathrm{HfM} \alpha), \mathrm{HoPO}_{4}$ $(\mathrm{HoL} \beta)$, chalkopyrit $(\mathrm{CuK \alpha})$, klinoklas $(\mathrm{As} L \alpha), \mathrm{LaPO}_{4}$ $(\mathrm{La} L \alpha), \mathrm{LiF}(\mathrm{FK} \alpha), \mathrm{LuPO}_{4}(\mathrm{Lu} L \alpha), \mathrm{Nb}(\mathrm{Nb} L \alpha), \mathrm{NdPO}_{4}$ $(\mathrm{Nd} L \beta), \mathrm{Ni}(\mathrm{NiK} \alpha), \mathrm{PrPO}_{4}(\operatorname{Pr} L \beta), \mathrm{Rb}-\mathrm{Ge}$-sklo $(\mathrm{Rb} L \alpha)$, rodonit $(\mathrm{MnK} \alpha)$, sanidin $(\mathrm{K} K \alpha, \mathrm{Si} K \alpha, \mathrm{AlK \alpha}), \mathrm{ScVO}_{4}(\mathrm{ScK} \alpha)$, scheelit $(\mathrm{W} L \alpha), \mathrm{SmPO}_{4}(\mathrm{Sm} L \alpha), \mathrm{Sn}(\mathrm{Sn} L \alpha), \mathrm{TbPO}_{4}$ $(\mathrm{Tb} L \alpha)$, Th $(\mathrm{Th} M \alpha), \mathrm{TiO}_{2}(\mathrm{TiK} \alpha), \mathrm{TmPO}_{4}(\mathrm{Tm} L \alpha), \mathrm{UO}_{2}$ $(\mathrm{UM} \alpha), \mathrm{V}(\mathrm{V} K \alpha)$, vanadinit $(\mathrm{PbM} \alpha)$, wollastonit $(\mathrm{CaK} \alpha$, $\mathrm{SiK} \alpha)$, wulfenit $(\mathrm{MoL} \alpha), \mathrm{YbPO}_{4}(\mathrm{Yb} L \alpha), \mathrm{YVO}_{4}(\mathrm{Y} L \alpha)$, zinkit $(\mathrm{ZnK} \alpha)$, zirkon $(\mathrm{Zr} L \alpha)$. Měřící časy na píku se pohybovaly obvykle mezi 10 a $30 \mathrm{~s}$ (pro dusík $120 \mathrm{~s}$ ), měřící časy pozadí trvaly polovinu času měření na píku. Načtená data byla přepočitána na obsahy oxidů vyjádřené v hm. \%, s použitím standardní PAP korekce (Pouchou, Pichoir 1985). Získaná data byla korigována na koincidence La vs. Dy, Eu vs. Dy, F vs. Ce, Bi vs. Ce a Th vs. U. Obsahy výše uvedených prvků, které nejsou uvedeny v tabulkách, byly ve všech prípadech pod mezí stanovitelnosti. Normalizace obsahů prvků vzácných zemin byla provedena na $\mathrm{C} 1$ chondrit s využitím dat Anderse a Grevesseho (1989). Výpočet velikosti Ce a Eu anomálií byl proveden podle vztahů McLennana (1989).

Polymorfní modifikace $\mathrm{TiO}_{2}$ byly rozlišeny in situ $v$ nábrusech za pomoci Ramanova disperzního spektrometru DXR (Thermo Scientific) s konfokálním mikroskopem Olympus (Národní muzeum). Ramanova spektra byla získána za použití červeného laseru (633 nm) o výkonu $8 \mathrm{~mW}$ v měřícím rozsahu $45-4000 \mathrm{~cm}^{-1}$, za použití objektivu $50 \times$ a apertury $50 \mu \mathrm{m}$ pin. Jedno spektrum bylo načítáno 10 minut (expoziční čas 3 s, 200 skenů). Získaná spektra byla následně pomocí obslužného softwaru Omnic 9 automaticky porovnána s referenčními spektry v databázi RRUFF. Číselné hodnoty maxim jednotlivých pásů ve spektrech byly vizualizovány $v$ tomtéž programu.

Tabulka 1 Přiklady chemického složení plagioklasu (Plg) a K-živce (Kfs) z pohledských pegmatitů. Obsahy oxidů $v \mathrm{hm}$. \%, hodnoty apfu jsou vypočitány na základ 8 atomů kyslíku. Obsahy koncových členů v mol. \%.

\begin{tabular}{|c|c|c|c|c|c|c|c|c|c|c|}
\hline An. č. & 1 & 2 & 3 & 4 & 5 & 6 & 7 & 8 & 9 & 10 \\
\hline Fáze & Plg & Plg & Plg & Plg & Plg & Plg & Plg & $\mathrm{Kfs}$ & Kfs & Kfs \\
\hline $\mathrm{P}_{2} \mathrm{O}_{5}$ & 0 & 0 & 0.05 & 0.23 & 0 & 0.23 & 0 & 0 & 0 & 0 \\
\hline $\mathrm{SiO}_{2}$ & 69.09 & 67.61 & 69.01 & 66.91 & 61.89 & 60.58 & 58.14 & 65.44 & 64.42 & 65.63 \\
\hline $\mathrm{Al}_{2} \mathrm{O}_{3}$ & 19.26 & 19.29 & 19.12 & 19.25 & 22.82 & 23.78 & 24.46 & 17.96 & 18.08 & 17.30 \\
\hline $\mathrm{Fe}_{2} \mathrm{O}_{3}$ & 0 & 0.30 & 0.14 & 0.10 & 0 & 0 & 0.09 & 0 & 0.20 & 0.10 \\
\hline $\mathrm{CaO}^{\circ}$ & 0.08 & 0.19 & 0.22 & 1.57 & 5.55 & 6.76 & 7.85 & 0 & 0 & 0 \\
\hline SrO & 0.12 & 0 & 0.11 & 0 & 0 & 0 & 0 & 0 & 0 & 0.19 \\
\hline $\mathrm{Na}_{2} \mathrm{O}$ & 11.64 & 11.84 & 11.59 & 11.00 & 8.28 & 7.65 & 6.90 & 0.31 & 0.38 & 0.19 \\
\hline $\mathrm{K}_{2} \mathrm{O}$ & 0 & 0.06 & 0 & 0.08 & 0.19 & 0.11 & 0.10 & 16.30 & 16.14 & 16.45 \\
\hline Celkem & 100.19 & 99.29 & 100.24 & 99.14 & 98.73 & 99.11 & 97.54 & 100.01 & 99.22 & 99.86 \\
\hline $\mathrm{P}^{5+}$ & 0 & 0 & 0.002 & 0.009 & 0 & 0.009 & 0 & 0 & 0 & 0 \\
\hline $\mathrm{Si}^{4+}$ & 3.009 & 2.984 & 3.007 & 2.960 & 2.778 & 2.716 & 2.662 & 3.020 & 3.003 & 3.040 \\
\hline $\mathrm{Al}^{3+}$ & 0.989 & 1.003 & 0.982 & 1.004 & 1.207 & 1.257 & 1.320 & 0.977 & 0.993 & 0.945 \\
\hline $\mathrm{Fe}^{3+}$ & 0 & 0.010 & 0.005 & 0.003 & 0 & 0 & 0.003 & 0 & 0.007 & 0.003 \\
\hline $\mathrm{Ca}^{2+}$ & 0.004 & 0.009 & 0.010 & 0.074 & 0.267 & 0.325 & 0.385 & 0 & 0 & 0 \\
\hline $\mathrm{Sr}^{2+}$ & 0.003 & 0 & 0.003 & 0 & 0 & 0 & 0 & 0 & 0 & 0.005 \\
\hline $\mathrm{Na}^{+}$ & 0.983 & 1.013 & 0.979 & 0.944 & 0.721 & 0.665 & 0.612 & 0.028 & 0.034 & 0.017 \\
\hline $\mathrm{K}^{+}$ & 0 & 0.003 & 0 & 0.005 & 0.011 & 0.006 & 0.006 & 0.960 & 0.960 & 0.972 \\
\hline Suma kat. & 4.988 & 5.023 & 4.988 & 4.999 & 4.984 & 4.978 & 4.988 & 4.985 & 4.998 & 4.982 \\
\hline$A b$ & 99.3 & 98.8 & 98.7 & 92.3 & 72.2 & 66.8 & 61.0 & 2.8 & 3.5 & 1.7 \\
\hline Or & 0 & 0.3 & 0 & 0.4 & 1.1 & 0.6 & 0.6 & 97.2 & 96.5 & 97.8 \\
\hline An & 0.4 & 0.9 & 1.0 & 7.3 & 26.7 & 32.6 & 38.4 & 0 & 0 & 0 \\
\hline Slw & 0.3 & 0 & 0.3 & 0 & 0 & 0 & 0 & 0 & 0 & 0.5 \\
\hline Celkem & 100 & 100 & 100 & 100 & 100 & 100 & 100 & 100 & 100 & 100 \\
\hline
\end{tabular}




\section{Charakteristika zjištěných minerálů}

Křemen je na některých vzorcích pegmatitu hlavní složkou, jindy se vyskytuje jen akcesoricky. Je přitomen ve dvou generacích. Starší křemen vytváří masivní šedobílá, xenomorfně omezená zrna, srůstající zejména se živci, o velikosti až $2 \mathrm{~cm}$. V některých vzorcích nelze vyloučit, že starší křemen byl během pozdějšího hydrotermálního vývoje pegmatitu vyloužen a dutiny po něm byly druhotně vyplněny amfibolem, chloritem, sulfidy či kalci- tem. V oblasti amfibolových hnízd byl v mikroskopických preparátech zjištěn i mladší křemen (často $v$ automorfně omezených průřezech) hojně uzavírající automorfně omezené jehlice amfibolu (obr. 2a,b).

Plagioklas je také podstatnou složkou všech studovaných vzorků. Je prítomen hlavně v podobě hypautomorfně až xenomorfně omezených individuí centimetrových velikostí, které mají makroskopicky bílou, oranžovou či světle zelenou barvu (obr. 2c). V mikroměřítku bývají
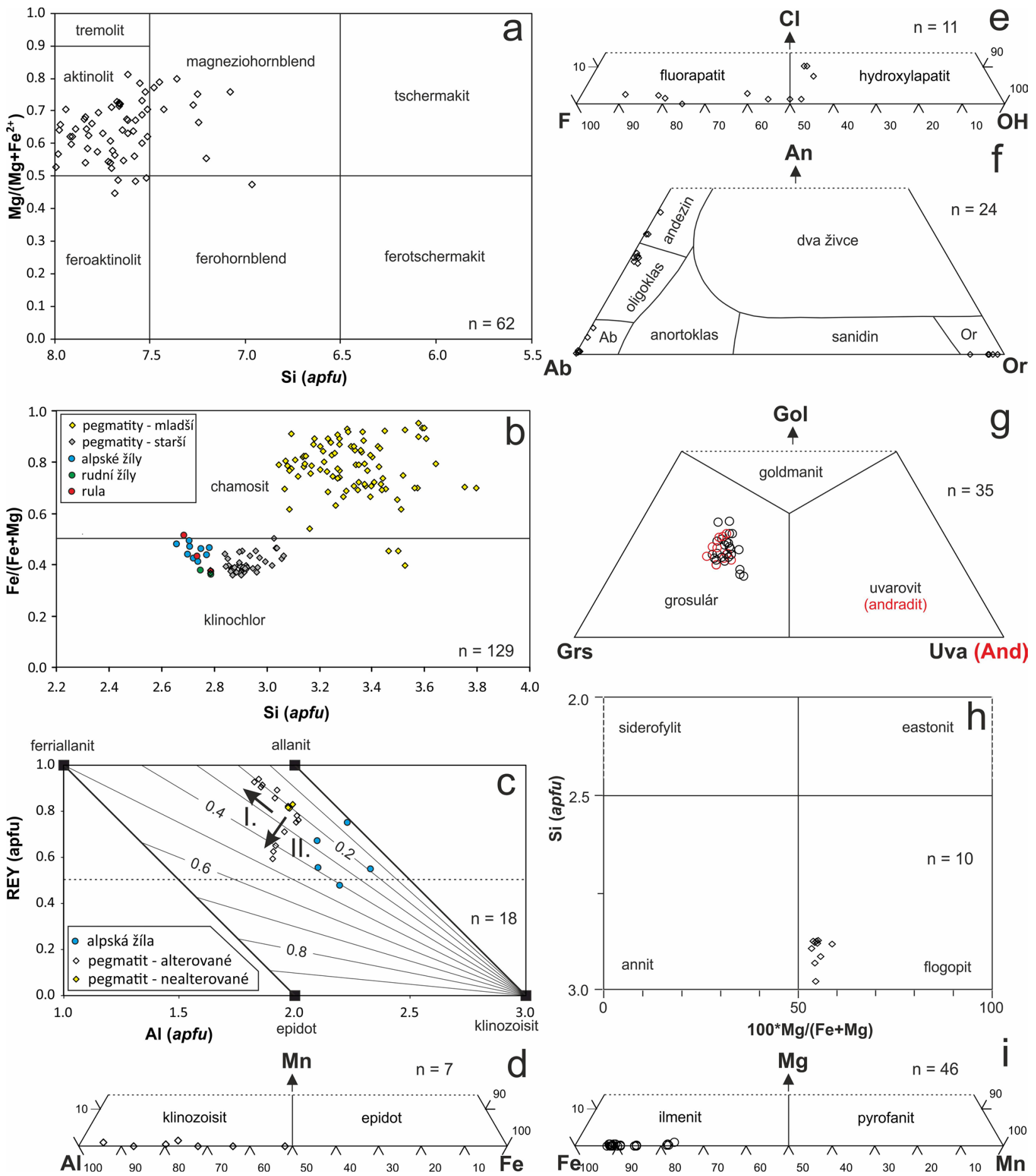

Obr. 3 Klasifikace chemicky analyzovaných minerálních fází a porovnání s publikovanými údaji z lomu Pohled. a - amfiboly v diagramu Leakeho et al. (1997); b - chlority v diagramu Baylisse (1975), srovnávací data převzata z prací Mastíkové (2009, 2011); c - allanity v diagramu Petríka et al. (1995) a Gierého, Sörensena (2004), srovnávací data převzata z prací Mastíkové (2009, 2011); d - klinozoisity v diagramu klinozoisit-epidot-piemontit; e - apatity v diagramu fluorapatit-chlorapatit-hydroxylapatit; $f$ - živce $v$ diagramu albit-ortoklas-anortit; $g$ - granáty $v$ diagramu grosulárgoldmanit-andradit/uvarovit; $h$ - biotit v diagramu Riedera et al. (1998); $i$ - ilmenit v diagramu ilmenit-pyrofanit-geikielit. 
plagioklasy místy od okrajů zrn a podél štěpnosti zatlačovány prehnitem, chloritem a klinozoisitem. V BSE obraze nevykazují plagioklasy žádnou výraznou zonalitu. Homogenitu chemického složení v rámci jednoho a téhož vzorku většinou potvrdily i analýzy na mikrosondě, byly však zjištěny poměrně výrazné rozdíly v chemismu plagioklasů z různých vzorků (srv. tab. 1). Klasifikačně jde o albity až andezíny $\left(\mathrm{An}_{0.7-38.4} \mathrm{Or}_{0.0-2.1} \mathrm{Slw}_{0.0-0.4}\right)$ - viz obr. 3f. Texturně se plagioklasy $\mathrm{s}$ rưznou bazicitou od sebe nijak výrazně neliší. Více než polovina získaných analýz měla i zvýšené obsahy fosforu (až 0.011 apfu P). Druhou formou výskytu jsou perthitické odmíšeniny $\vee$ K-živci, jež jsou tvořeny prakticky čistým albitem $\left(\mathrm{An}_{0.0-0.8} \mathrm{Or}_{0.0-0.5}\right)$.

K-živec je relativně hojným minerálem, i když je přítomen v menším množství než plagioklas. Vytváří bílá či růžová, xenomorfně omezená izometrická až mírně pro- tažená zrna o velikosti až prvních centimetrů. Za čerstva má skelný lesk, který se mění v důsledku počínající argilitizace až na matný. $V$ radě prípadů obsahuje perthitické odmíšeniny albitu. Chemické složení K-živce je jednoduché (tab. 1, obr. 3f), vedle převažující ortoklasové složky (92.0 - 97.8 mol. \%) obsahuje i malý podíl albitové (1.7 - 8.0 mol. \%) a vzácně i slawsonitové (max. 0.5 mol. \%) a celsianové (max. 0.3 mol. \%) komponenty.

Amfibol reprezentuje hlavní složku amfibolových hnízd, které se někdy vyskytují v centrálních částech pegmatitových výplní mezer v brekciích okolních metamorfitů. Ojediněle byly pozorovány i tenké (do $0.5 \mathrm{~cm}$ mocné) křemen-amfibolové žilky, protínající křemen-živcovou hmotu. Amfibol má makroskopicky šedozelenou barvu a vytváří stébelnaté, jehlicovité či radiálně paprsčité agregáty, v nichž jednotlivá individua dosahují délky až několi-

Tabulka 2 Přiklady chemického složení amfibolu (Amp) a biotitu (Bt) z pohledských pegmatitů. Obsahy oxidů v hm. \%, hodnoty apfu jsou vypočitány na základ 22 atomů kyslíku +2(OH+F+Cl) a 13 kationtů eCNK (amfiboly), resp. 10 atomů kyslíku $+2(\mathrm{OH}+\mathrm{F}+\mathrm{Cl})$ (biotit). * - obsah $\mathrm{H}_{2} \mathrm{O}$ dopočten ze stechiometrie. $\mathrm{F} / \mathrm{FM}=\mathrm{Fe}^{2+} /\left(\mathrm{Fe}^{2+}+\mathrm{Mg}\right)$.

\begin{tabular}{|c|c|c|c|c|c|c|c|c|c|c|c|c|c|c|}
\hline An. č. & 1 & 2 & 3 & 4 & 5 & 6 & 7 & 8 & 9 & 10 & 11 & 12 & 13 & \\
\hline Minerál & Amp & Amp & Amp & Amp & Amp & Amp & Amp & Amp & Amp & Amp & $\mathrm{Bt}$ & $\mathrm{Bt}$ & $\mathrm{Bt}$ & \\
\hline${ }_{2} \mathrm{O}_{5}$ & 0 & 0 & 0 & 0 & 0.18 & 0 & 0 & 0 & 0.07 & 0.06 & 0 & 0 & 0 & \\
\hline $\mathrm{O}_{2}$ & 51.38 & 54.26 & 53.60 & 50.38 & 52.82 & 53.67 & 51.57 & 1.42 & 51.77 & 48.60 & 36.60 & 37.04 & 37.74 & \\
\hline $\mathrm{iO}_{2}$ & 0 & 0.23 & 0.23 & 0.12 & 0 & 0.08 & 0 & 0 & 0.40 & 0.19 & 2.08 & 1.97 & 3.35 & \\
\hline $\mathrm{rO}_{2}$ & 0 & 0 & 0 & 0 & 0.27 & 0 & 0.08 & 0 & 0 & 0.09 & & & & \\
\hline $\mathrm{I}_{2} \mathrm{O}_{3}$ & 1.07 & 2.16 & 0.82 & 3.35 & 2.49 & 2.31 & 4.06 & 3.15 & 3.92 & 5.23 & 14.83 & 15.22 & 13.11 & \\
\hline${ }_{2} \mathrm{O}_{3}$ & 0 & 0.33 & 0 & 0.07 & 0.13 & 0 & 0 & 0 & 0.12 & 0.19 & 0.06 & 0.07 & 0.09 & \\
\hline $\mathrm{r}_{2} \mathrm{O}_{3}$ & 0 & 0 & 0 & 0 & 0 & 0 & 0 & 0 & 0 & 0.29 & 0.08 & 0.05 & 0 & \\
\hline $\mathrm{e}_{2} \mathrm{O}_{3}$ & 0 & 0 & 2.71 & 0 & 0.98 & 6.01 & 0.70 & 4.14 & 5.47 & 3.73 & & & & \\
\hline $\mathrm{gO}^{2}$ & 30 & .85 & 3.63 & 9.82 & 5.51 & 16.45 & 11.78 & 33 & 6.17 & 10.80 & 11.35 & 11.67 & 11.66 & \\
\hline 0 & 88 & 30 & 0.76 & 0.58 & 0.42 & 49 & 0.31 & 53 & 0.41 & 0.42 & 0.23 & 0.21 & 0.17 & \\
\hline b & 2.13 & .90 & 13.41 & 18.44 & .05 & 6.81 & .34 & & 7.24 & 15.48 & 17.05 & 17.23 & 17.52 & \\
\hline 0 & 37 & 51 & 1 & 8 & & & 37 & & 78 & 12.28 & 0 & 0 & 0 & \\
\hline $\mathrm{a}_{2} \mathrm{O}$ & & 36 & 0.48 & & 19 & 23 & 0.37 & 0 & 1.12 & 0.56 & 0.19 & 0.10 & 12 & \\
\hline${ }_{2}^{2}$ & 16 & 0 & 0.05 & 0.24 & 0.06 & 0.09 & 0.20 & 08 & 0.13 & 0.27 & 8.60 & 8.70 & .58 & \\
\hline $\mathrm{F}$ & 0 & 30 & 0 & 0 & 0.14 & 0.19 & 0 & 0 & 0.12 & 0.14 & 0.77 & 0.71 & 29 & \\
\hline & 0.06 & 0 & 0 & 5 & 0 & 0 & 0 & 0 & 0 & 0.10 & 0.04 & 0.06 & 0.04 & \\
\hline . & & 92 & 05 & 6 & 00 & 2.02 & .04 & .03 & 2.10 & 1.93 & 3.44 & 3.51 & 71 & \\
\hline$=\mathrm{F}+\mathrm{Cl}$ & 01 & -0.13 & 0 & 0.01 & -0.06 & -0.08 & 0 & 0 & -0.05 & -0.08 & -0.33 & -0.31 & -0.13 & \\
\hline elkem & 86 & 99 & 55 & 58 & 90 & 25 & .82 & 35 & 100.76 & 100.28 & 94.99 & 96.23 & 96.25 & \\
\hline & 0 & 0 & 0 & 0 & 0.022 & 0 & 0 & 0 & 0.008 & 0.008 & 0 & 0 & 0 & \\
\hline $1+$ & 00 & 05 & 33 & & 7.664 & 16 & 583 & 76 & 58 & 203 & 80 & 2.874 & 32 & \\
\hline & 0 & 25 & 25 & 14 & 0 & 99 & 0 & 0 & 43 & 0.021 & 0.123 & 0.115 & 0.196 & \\
\hline & 0 & 0 & 0 & 0 & & 0 & 06 & 0 & 0 & 0.007 & & & & \\
\hline & 96 & 71 & 41 & & 26 & 386 & 704 & 47 & & 14 & & 92 & 201 & \\
\hline V & 0 & 39 & 0 & 9 & 15 & 0 & 0 & 0 & & 23 & 04 & 0.004 & 0.006 & 0. \\
\hline C & 0 & 0 & 0 & 0 & 0 & 0 & 0 & 0 & 0 & 0.051 & 0.007 & 0.005 & 0 & \\
\hline+ & 0 & 0 & 98 & 0 & & 42 & 77 & & & 0.416 & & & & \\
\hline & & 91 & & 28 & & & & & & & & & 50 & 1.4 \\
\hline & & & & & & & & & & 53 & 0.015 & 0.014 & 0.011 & 0.0 \\
\hline$e^{2+}$ & 2 & 94 & 9 & 7 & 1 & 8 & 9 & 24 & 1 & 19 & 1.122 & 1.118 & 1.138 & \\
\hline & & & & & & & & 1.913 & & & 0 & 0 & 0 & \\
\hline & & 0.102 & & & & & & 0 & & & 0.029 & & 18 & \\
\hline $\mathrm{K}^{+}$ & 0.032 & 0 & 009 & 0.047 & .011 & 0.016 & 0.038 & 0.015 & 0.023 & 051 & 0.863 & 0.861 & 0.850 & 0.8 \\
\hline Sum & 34 & 14.916 & 14.995 & 15.080 & 15.042 & 14.901 & 92 & 4.928 & 15.125 & 15.162 & 7.750 & 7.748 & 7.703 & 7.7 \\
\hline$\overline{F^{-}}$ & 0 & 0.138 & 0 & 0 & 0.064 & 0.085 & 0 & 0 & 0.053 & 0.066 & 0.192 & 0.174 & 0.071 & 0.0 \\
\hline & & 0 & 0 & & 0 & 0 & 0 & 0 & 0 & 0.025 & 0.005 & 0.008 & 0.005 & \\
\hline $\mathrm{OH}^{-}$ & & 66 & 98 & & & 12 & 01 & 95 & 51 & 1.908 & 1.805 & 1.816 & 1.922 & 1.9 \\
\hline Suma an. & 1.999 & 2.004 & 1.998 & 2.003 & 2.000 & 1.997 & 2.001 & 1.995 & 2.003 & 1.999 & 2.002 & 1.999 & 1.999 & 1.95 \\
\hline$\overline{F / F M}$ & 0.63 & 0.38 & 0.36 & 0.51 & 0.29 & 0.19 & 0.44 & 0.33 & 0.20 & 0.45 & 0.46 & 0.45 & 0.46 & \\
\hline Klasifik. & Fac & Act & Act & Fac & Act & Act & Act & Act & Mhb & Mhb & Phl & $\mathrm{Phl}$ & $\mathrm{Phl}$ & \\
\hline
\end{tabular}


ka centimetrů a šírky desetin milimetru až prvních milimetrů (obr. 2). V mikroměřítku bývá často obklopován, někdy až zatlačován chloritem a sulfidy (obr. 2d,e). V okrajových částech hnízd jehlice amfibolu prorůstají do okolních živců (obr. 2f). Ve výbruse je světle zelený (obr. 2a). Jehlice většinou vykazují šikmé zhášení vůči protažení $(\gamma / c=0$ $8^{\circ}$ ). V BSE obraze je někdy viditelná chemická zonálnost, kdy tmavší jádra zrn jsou chudší železem a bohatší hořčíkem, nežli světlejší okraje. Mikrosondové analýzy (tab. 2) ukázaly příslušnost $\mathrm{k}$ podskupině vápenatých amfibolù.
Při přepočtu empirického vzorce na bázi 23 kyslíků se obsahy Si pohybují mezi 6.97 a 8.00 apfu, Al mezi 0.07 a 1.38 apfu, Mg mezi 1.69 a 3.48 apfu, $\mathrm{Fe}^{2+}$ mezi 0.81 a 2.88 apfu, Ca mezi 1.75 a 2.04 apfu, Ti dosahuje max. 0.04 apfu, $\mathrm{Fe}^{3+}$ max. 1.02 apfu. V A-pozici krystalochemického vzorce je prítomno maximálně 0.20 apfu $\mathrm{Na}+\mathrm{K}$. Poměr $\mathrm{Mg}^{2+} /\left(\mathrm{Fe}^{2+}+\mathrm{Mg}^{2+}\right)$ kolísá mezi 0.37 a 0.81 (tab. 2). V klasifikačním schématu Leakeho et al. (1997) jde tedy většinou o aktinolit, méně magneziohornblend a feroaktinolit, vzácně ferohornblend (obr. 3a).
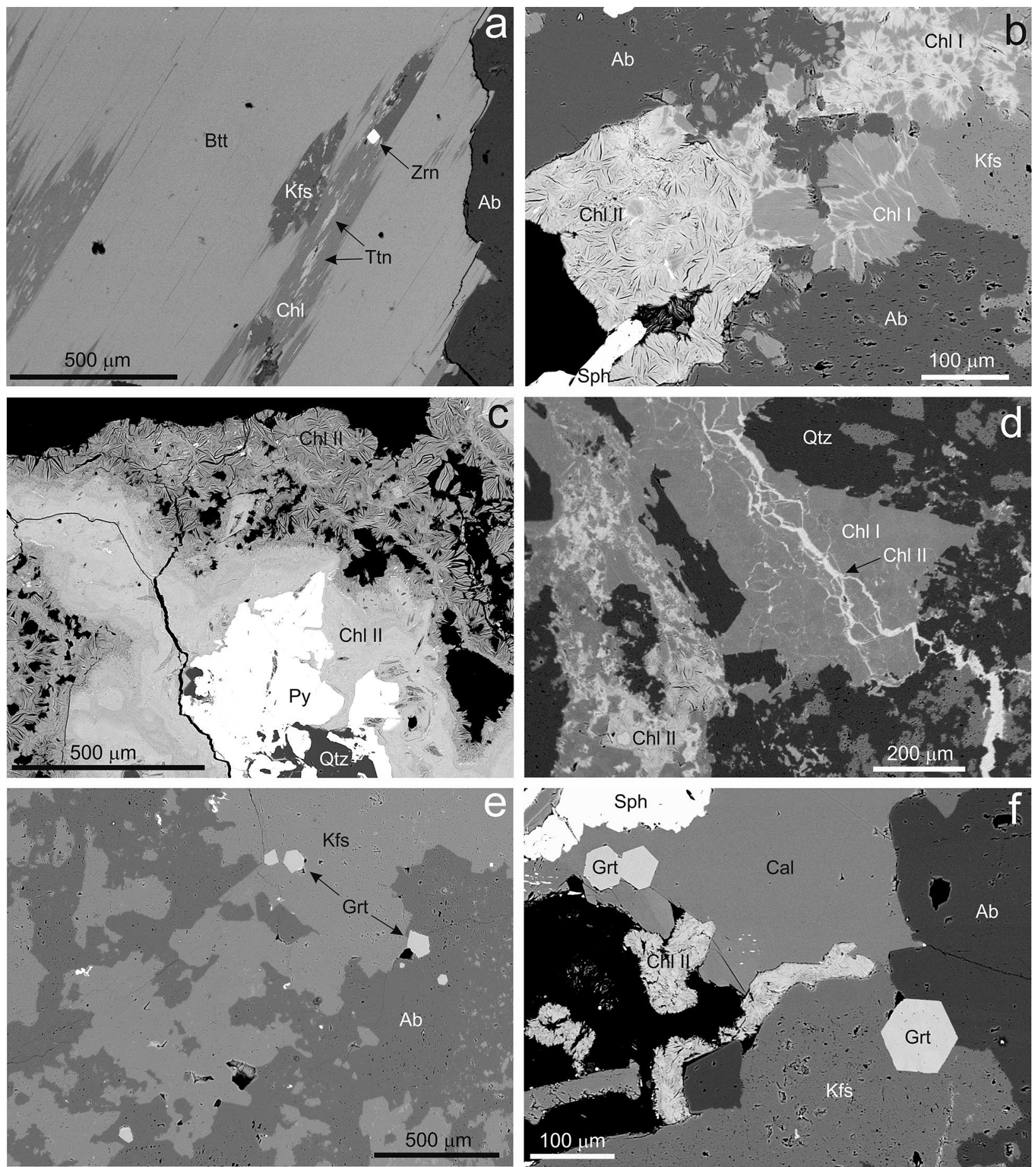

Obr. 4 Minerální asociace a vývin minerálů ze studovaných pegmatitů z lomu Pohled na BSE snímcích. a - kompozičně homogenní biotit (Btt), podél štěpnosti zatlačovaný chloritem (Chl) s inkluzemi titanitu (Ttn). Zrn - zirkon, Ab - albit, Kfs - K-živec. b - dvě generace chloritu (Chl I, Chl II) s odlišným složením. Sph - sfalerit. c - př́klad zonality mladší generace chloritu (Chl II). Qtz - křemen, Py - pyrit. $d$ - dvě generace chloritu, mladší generace (Chl II) vyhojuje trhlinky ve starší (Chl I). e - automorfní krystaly granátu uzavřené v živcích (Kfs, Ab). $f$ - automorfní krystaly granátu uzavřené v živcích (Kfs, Ab) a kalcitu (Cal). Všechny snímky Z. Dolníček. 
Biotit je charakteristickým minerálem pohledských pegmatitů, který bývá běžně zarostlý v křemen-živcové hmotě; nikdy nebyl ve vzorcích zaznamenán společný výskyt biotitu a amfibolu. Biotit vytváří hypautomorfně až automorfně omezené, tence až tlustě tabulkovité krystaly, které dosahují velikosti až $4 \mathrm{~cm}$. Makroskopicky má černou barvu, ve výbruse je tmavohnědý, silně pleochroický. V BSE obraze nevykazuje zonálnost (obr. 4a). Tabulky bývají někdy od okrajů či podél trhlin slabě zatlačovány chloritem, prípadně chloritem s inkluzemi titanitu (obr. 4a) a případně i rutilu. Chemické složení je podle získaných WDS analýz velmi homogenní i při porovnání různých zrn. Vyznačuje se zvýšenými obsahy Ti $(0.11-0.20$ apfu při přepočtu na bázi 11 atomů kyslíku), $\mathrm{Na}(0.01-0.03$ apfu), $\mathrm{F}$ (0.07 - 0.20 apfu), někdy i $\mathrm{Cr}, \mathrm{Zn}, \mathrm{V}$ a $\mathrm{Cl}$ (max. 0.01 apfu). Obsah Mg (1.29 - 1.48 apfu) převažuje nad Fe (1.04 - 1.16 apfu), obsah Si kolísá mezi 2.87 a 2.98 apfu. Poměr $\mathrm{Fe} /(\mathrm{Fe}+\mathrm{Mg})$ se pohybuje mezi 0.41 a 0.47 a obsah mezivrstevních kationtů mezi 0.85 a 0.91 apfu (tab. 2). Klasifikačně jde tedy o flogopit (Rieder et al. 1998; viz obr. 3h).

Chlorit je velmi hojně zastoupeným alteračním minerálem. Zatlačuje živce, biotit a amfiboly. Do volných dutin vytváŕi povlaky a ledvinité agregáty makroskopicky černozelené barvy o velikosti až prvních milimetrů, složené z vějiŕrovitě uspořádaných šupinek. Monominerální agregáty chloritu jsou tvořené stejnorozměrnými až tabulkovitými individui o velikosti max. $0.1 \mathrm{~mm}$, s xenomorfním až hypautomorfním omezením. V obraze BSE jsou chloritové agregáty a zrna zpravidla kompozičně zonální, při- čemž starší partie bývají tmavší než krystalizačně mladší okraj agregátů (obr. 4b,c). Mladší chlority někdy i vyhojuji drobné trhlinky ve starším chloritu (obr. 4d). Parageneticky mladší partie chloritových agregátů ve vakuu snáze ztrácejí vodu a mnohem výrazněji se smrštují (za vzniku otevřených dilatačních puklin) než starší partie (obr. 4b,c). Rozdíl je i v optických vlastnostech ve výbruse chlority starší generace mají v PPL světle zelenou barvu a $\vee$ XPL anomální zelenou interferenční barvu, zatímco chlority mladší generace vykazují v PPL obvykle žlutavé až hnědavé zbarvení a $v$ XPL anomální modrou interferenční barvu. Ojediněle byla pozorována inkrustace chloritu limonitem podél intergranulár nebo štěpných trhlin.

Podrobně bylo studováno chemické složení chloritů - celkem bylo provedeno 135 bodových WDS analýz, jejichž reprezentativní výběr je uveden v tabulce 3 . Chemické složení obou generací chloritu je rozdílné. $V$ případě starší generace se při přepočtu empirického vzorce na bázi 14 atomů kyslíku pohybují obsahy Si mezi 2.78 a 3.06 apfu. Obsahy $\mathrm{Ca}$ a $\mathrm{K}$ jsou většinou pod mezí stanovitelnosti nebo nepřevyšují hodnotu 0.02 , respektive 0.03 apfu, zatímco zvýšené bývají obsahy Mn (0.02 $0.05 \mathrm{apfu})$ a často i $\mathrm{Cr}(\max .0 .07 \mathrm{apfu})$ a $\mathrm{V}(\max .0 .02$ $a p f u$ ). Poměr $\mathrm{Fe} /(\mathrm{Fe}+\mathrm{Mg}$ ) kolísá mezi 0.36 a 0.50 (tab. 3, obr. 5a). Jde tedy o trioktaedrické Fe-Mg-Al chlority klinochlor-chamositové raady (Wiewióra, Weiss 1990), jejichž chemické složení odpovídá klinochloru v klasifikacích Baylisse (1975; obr. 3b) i Melky (1965). Mladší generace chloritu má při přepočtu empirického vzorce na bázi 14 atomů kyslíku většinou v porovnání se starší generací

Tabulka 3 Příklady chemického složení chloritu z pohledských pegmatitů (st - starší, ml - mladši generace chloritu). Obsahy oxidů v hm. \%, hodnoty apfu jsou vypočitány na základ 14 atomů kyslíku. $T\left({ }^{\circ} \mathrm{C}\right)$ - teplota podle Cathelineau (1988). F/FM - Fe/(Fe+Mg).

\begin{tabular}{|c|c|c|c|c|c|c|c|c|c|c|c|c|c|c|}
\hline An. č. & 1-st & 2-st & 3-st & 4-st & 5-st & 6-ml & 7-ml & 8-ml & 9-ml & 10-ml & $11-\mathrm{ml}$ & $12-\mathrm{ml}$ & 13-ml & 14-ml \\
\hline $\mathrm{SiO}_{2}$ & 7.91 & 8.49 & 27.19 & 28.97 & 27.36 & 26.60 & 25.69 & 28.90 & 28.85 & 30.43 & 32.09 & 33.78 & 39.65 & 40.60 \\
\hline $\mathrm{Al}_{2} \mathrm{O}_{3}$ & 9.20 & 19.66 & 19.68 & 20.01 & 16.91 & 15.67 & 14.45 & 13.58 & 9.80 & 13.71 & 12.10 & 9.56 & 7.74 & 8.43 \\
\hline $\mathrm{V}_{2} \mathrm{O}_{3}$ & 0.12 & 0.10 & 0 & 0 & 0.13 & 0 & 0 & 0 & 0 & 0 & 0 & 0 & 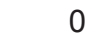 & 0 \\
\hline $\mathrm{Cr}_{2} \mathrm{O}_{3}$ & 0.55 & 0.24 & 0 & 0 & 0.10 & 0 & 0 & 0 & 0 & 0 & 0 & 0 & 0 & 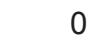 \\
\hline $\mathrm{MgO}$ & 8.79 & 18.58 & 16.94 & 8.31 & 16.75 & 5.83 & 2.41 & 3.64 & 8.07 & 6.68 & 7.94 & 7.96 & 12.18 & 9.54 \\
\hline nO & 0.40 & 0.31 & 0.58 & 0.39 & 0.23 & 0.28 & 0.15 & 0.12 & 0.25 & 0.27 & 0.20 & 0.12 & 0.15 & 0 \\
\hline $\mathrm{FeO}$ & 0.43 & 20.21 & 18.49 & 19.10 & 22.18 & 38.38 & 41.99 & 42.71 & 37.04 & 33.13 & 32.75 & 32.45 & 20.29 & 23.60 \\
\hline oO & 0 & 0 & 0 & 0 & 0 & 0.09 & 0 & 0.09 & 0 & 0.09 & 0 & 0 & 0 & 0.11 \\
\hline $\mathrm{NiO}$ & 0 & 0 & 0 & 0 & 0 & 0 & 0 & 0 & 0 & 0.10 & 0 & 0 & 0 & 0.19 \\
\hline $\mathrm{ZnO}$ & 0 & 0 & 0 & 0 & 0.17 & 0 & 0.42 & 0 & 0 & 0 & 0 & 0 & 0.61 & \\
\hline $\mathrm{CaO}$ & 0 & 0.05 & 0 & 0 & 0.05 & 0.32 & 0.18 & 0.36 & 0.32 & 0.65 & 1.16 & 0.87 & 1.69 & 1.37 \\
\hline $\mathrm{K}_{2} \mathrm{O}$ & 0 & 0 & 0 & 0 & 0 & 0 & 0 & 0 & 0.06 & 0 & 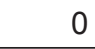 & .21 & 0.14 & 0.17 \\
\hline Celke & 7.40 & 87.64 & 82.88 & 6.78 & 83.88 & 87.17 & 5.29 & 89.40 & 84.39 & 5.06 & 86.24 & 4.95 & 82.45 & 4.01 \\
\hline $\mathrm{Si}^{4+}$ & 366 & 907 & .920 & 962 & 2.973 & 3.044 & 093 & 276 & 3.405 & 440 & 60 & .794 & 251 & 310 \\
\hline $\mathrm{Al}^{3+}$ & 324 & 2.365 & 491 & 412 & 2.166 & 114 & 051 & 814 & 1.363 & .827 & 1.582 & 1.266 & 0.978 & 1.055 \\
\hline $\mathrm{V}^{3+}$ & .010 & 0.008 & 0 & 0 & 0.011 & 0 & 0 & 0 & 0 & 0 & 0 & 0 & 0 & 0 \\
\hline $\mathrm{Cr}^{3+}$ & 067 & 0.029 & 0 & 0 & 0.013 & 0 & 0 & 0 & 0 & 0 & U & 0 & 0 & \\
\hline $\mathrm{Mg}^{2+}$ & 877 & 2.826 & 712 & 791 & 2.713 & 0.994 & 433 & 615 & 1.420 & .126 & 1.313 & .333 & 1.947 & 1.510 \\
\hline $\mathrm{Mn}^{2+}$ & 035 & 0.027 & 0.053 & .034 & 0.021 & 0.027 & 0.015 & 0.012 & 0.025 & 0.026 & 0.019 & 0.011 & 0.014 & 0 \\
\hline $\mathrm{Fe}^{2+}$ & 1.755 & 1.725 & 1.660 & 1.633 & 2.016 & 3.673 & 4.229 & 4.049 & 3.656 & 3.132 & 3.038 & 3.048 & 1.819 & 2.095 \\
\hline $\mathrm{Co}^{2+}$ & 0 & 0 & 0 & 0 & 0 & 0.008 & 0 & 0.008 & 0 & 0.008 & 0 & 0 & 0 & 0.009 \\
\hline $\mathrm{Ni}^{2+}$ & 0 & 0 & 0 & 0 & 0 & 0 & 0 & 0 & 0 & 0.009 & 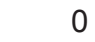 & 0 & 0 & 0.016 \\
\hline $\mathrm{Zn}^{2+}$ & 0 & 0 & 0 & 0 & 0.014 & 0 & 0.037 & 0 & 0 & 0 & 0 & 0 & 0.048 & 0 \\
\hline $\mathrm{Ca}^{2+}$ & 0 & .005 & 0 & 0 & 0.006 & 0.039 & 0.023 & .044 & 0.040 & 0.079 & 0.138 & 0.105 & 0.194 & 0.156 \\
\hline $\mathrm{K}^{+}$ & 0 & 0 & 0 & 0 & 0 & 0 & 0 & 0 & 0.009 & 0 & 0 & 0.030 & 0.019 & 0.023 \\
\hline Sum & 9.933 & 9.892 & 9.835 & 9.832 & 9.932 & 9.899 & 9.881 & 9.817 & 9.918 & 9.647 & 9.649 & 9.588 & 9.270 & 9.174 \\
\hline F/FM & 0.38 & 0.38 & 0.38 & 0.37 & 0.43 & 0.79 & 0.91 & 0.87 & 0.72 & 0.74 & 0.70 & 0.70 & 0.48 & 0.58 \\
\hline $\mathrm{T}\left({ }^{\circ} \mathrm{C}\right)$ & 303 & 290 & 286 & 272 & 269 & 246 & 230 & 171 & 130 & 118 & 80 & 4 & -143 & -162 \\
\hline
\end{tabular}


chloritu značně vyšší obsahy Ca (0.023 - 0.194 apfu), Si (3.04 - $4.31 \mathrm{apfu}$ ), většinou vyšší poměr $\mathrm{Fe} /(\mathrm{Fe}+\mathrm{Mg})$ mezi 0.40 a 0.95 (obr. 5a) a nižší obsahy Mn (0.00 - 0.03 apfu), $\mathrm{V}$ a $\mathrm{Cr}$ (obvykle pod mezí stanovitelnosti; tab. 3). Obsah křemíku je u šesti analýz dokonce vyšší, než je teoreticky možné maximum ve struktuře trioktaedrického chloritu (4.00 apfu). Obsah Si zřetelně $\left(R^{2}=0.74\right)$ pozitivně koreluje s obsahy $\mathrm{Ca}$ (obr. $5 \mathrm{~b}$ ), což nasvědčuje př́tomnosti příměsi Ca-smektitu v analyzovaném chloritu. $\mathrm{S}$ touto interpretací je v souladu i pozorovaná snadná ztráta vody ve vakuu a výraznější expandibilita dané fáze (obr. 4b,c). V malé části získaných analýz byly zaznamenány i zvýšené obsahy draslíku (max. $0.031 \mathrm{apfu}$ ), které nasvědčuji př́tomnosti slídové komponenty. V klasifikaci Baylisse (1975) jde většinou o chamosity, vzácně i o klinochlory (obr. 3b). Ve starší klasifikaci Melky (1965) padají průmětné body získaných analýz z mladší generace chloritu hlavně do pole delessitu, méně i chamositu a penninu.

Titanit je relativně běžnou akcesorií. Jednotlivá zrna jsou porůznu uzavírána $v$ pyritu a agregátech některých silikátových fází, zejména živců, amfibolů a chloritu (obr. 6a). Vůči živcům a amfibolům je zřetelně mladší (inkluze těchto fází běžně uzavírá). Často také obklopuje nebo i zatlačuje ilmenit (obr. 6b-f). Jeho hypautomorfně až xenomorfně omezená zrna dosahují velikosti až $0.8 \mathrm{~mm}$. V BSE obraze bývá titanit někdy zonální (obr. 6a) - světlejší sektory, růstové zóny či nepravidelně omezené domény, bohatší na Zr, Sn či Nb, jsou střídány tmavší matricí, která je chudší zmíněnými prvky a/nebo bohatší hliníkem. Mikrosondové analýzy $(\mathrm{n}=39)$ ukázaly, že vedle $\mathrm{Ca}, \mathrm{Ti}$ a Si v titanitu vždy vystupují i další prvky (tab. 4). Nejvyšší obsahy $\mathrm{Al}$ (0.32 - 0.37 apfu při přepočtu na bázi 3 kationtů) a $\mathrm{F}(0.34 \mathrm{apfu})$ byly zjištěny v drobných inkluzích titanitu, které spolu s chloritem vznikají zatlačováním biotitu. Naopak titanity uzavírané v živcích, amfibolech a dalších minerálech mají obsahy Al i F výrazně nižší (0.01 - 0.15 apfu Al, 0.00 - 0.03 apfu F). Mezi obsahy obou prvků je zřetelná pozitivní korelace $\left(R^{2}=0.86\right.$; obr. $\left.5 c\right)$. Dalšími průběžně přitomnými prvky jsou $\mathrm{Fe}(0.003-0.055$ apfu) a LREE (0.002 - 0.008 apfu La+Ce). Z dalších méně běžných príiměsí je třeba zmínit $\mathrm{Nb}$ (max. $0.013 \mathrm{apfu}$ ), Ta (max. 0.005 apfu), Zr (max. 0.021 apfu) a Sn (max. 0.029 apfu).

IImenit vytvárí tence až tlustě tabulkovité krystaly, príipadně nepravidelná zrna o velikosti až $2.5 \mathrm{~mm}$. Vyskytuje se poměrně vzácně $v$ intergranulárách živců, často $v$ asociaci s titanitem, chloritem a pyritem, které se vůči němu jeví jako mladší a často jej i od okrajů či podél trhlin zatlačují (obr. 6b-f). Vůči amfibolu je naopak starší. V některých prípadech (obr. 6c-f) ilmenit uzavírá inkluze rutilu a anatasu. $V$ odraženém světle je nahnědlý (obr. $6 \mathrm{c}, \mathrm{d}$ ), jeví slabý dvojodraz i anizotropii při částečně rozkřížených nikolech. V BSE obraze nevykazuje zonálnost (obr. 6e,f). Absenci výraznější kompoziční zonálnosti potvrdily i mikrosondové analýzy, byly však zjištěny rozdíly $v$ chemismu ilmenitů z různých vzorků. Reprezentativní výběr z 29 naměřených analýz ilmenitů je uveden v tabulce 4 . Vedle Fe a Ti byly pravidelně zjištěny zvýšené koncentrace manganu (0.07 - 0.22 apfu). V $75 \%$ naměřených analýz byly dále naměřeny slabě zvýšené koncentrace $\mathrm{Nb}$ (max. 0.004 apfu) a V (max. 0.002 apfu). Polovina analýz ukázala i malé koncentrace $\mathrm{Ca}(\max .0 .003 \mathrm{apfu})$ a Mg (max. 0.010 $a p f u$ ), ve čtvrtině analýz byly naměřeny i nízké obsahy $\mathrm{Zr}$ (max. $0.017 \mathrm{apfu}$ ), Y (max. $0.005 \mathrm{apfu}$ ) a Ta (max. 0.002 apfu). Uvedený chemismus odpovídá prítomnosti 76.4 92.5 mol. \% ilmenitové, 7.5 - 22.5 mol. \% pyrofanitové a 0.0 - 1.0 mol. \% geikielitové komponenty (obr. 3i).

Rutil byl zjištěn ve dvou formách výskytu. První byla nalezena pouze ve dvou vzorcích, $v$ nichž je rutil $v$ asociaci s ilmenitem, anatasem, pyritem a titanitem. Rutil je vždy př́tomen pouze uvnitř ilmenitových zrn a obě fáze nejsou nikdy ve vzájemném kontaktu, vždy jsou od sebe odděleny titanitem (obr. 6c-f). Rutil zde vytváří protažené hypautomorfně omezené lištovité prưřezy o délce maximálně $200 \mu \mathrm{m}$ a šířce do $50 \mu \mathrm{m}$, které se často shlukují do nepravidelných izometrických či protažených, slabě porézních agregátů o velikosti až $400 \mu \mathrm{m}$ (obr. 6c-f).
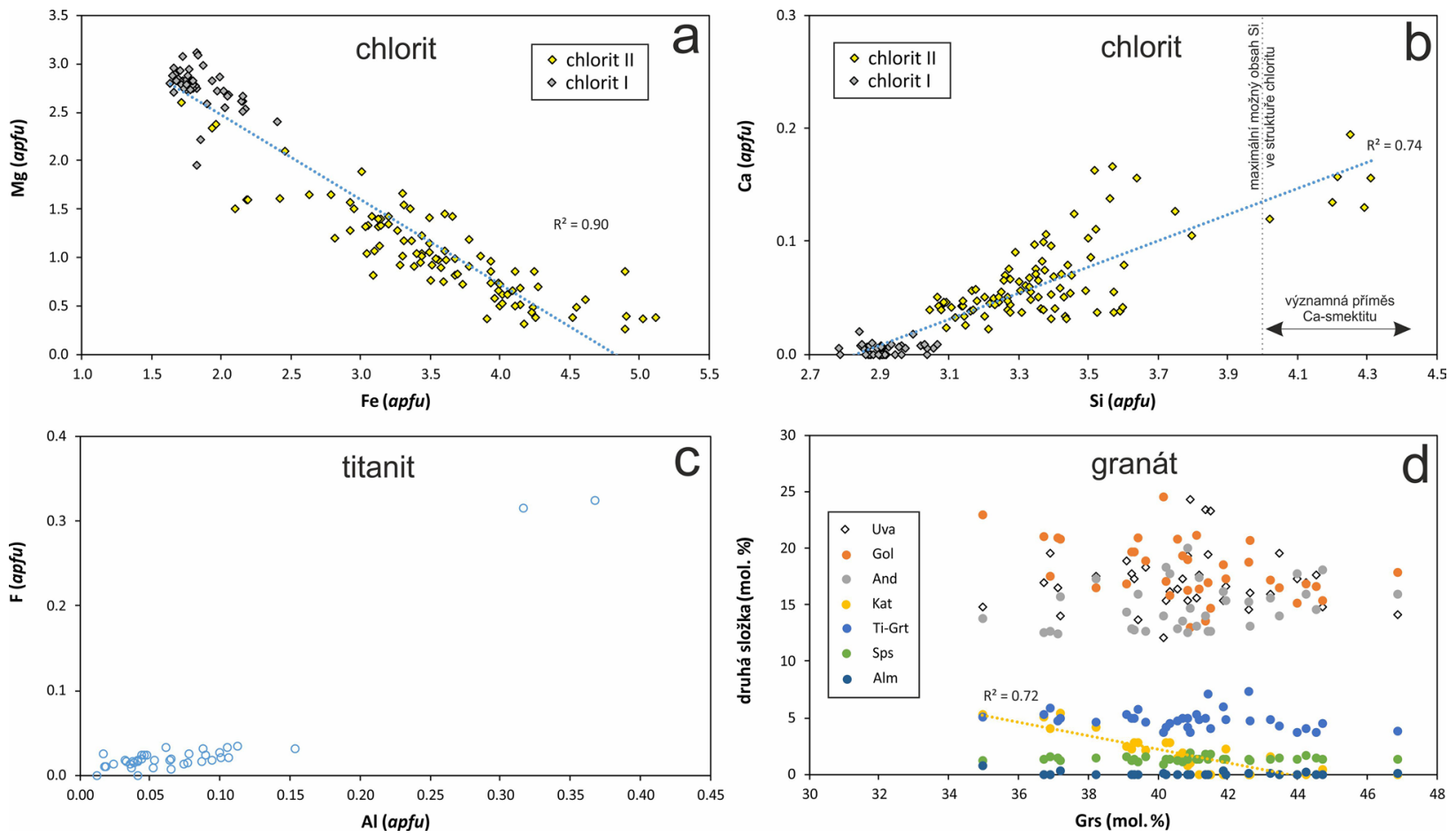

Obr. 5 Variace $v$ chemickém složení některých minerálních fází pohledských pegmatitů. a - diagram Fe - Mg v chloritech, b - diagram Ca - Si v chloritech, c - diagram Al - F v titanitech, d-diagram Grs versus ostatní složky v granátech. 
V odraženém světle je modravě šedý, anizotropní, s hojnými bílými vnitřními reflexy. V BSE obraze je někdy nevýrazně zonální. Jak ukázaly bodové analýzy (tab. 4), zonalita je způsobena variacemi v obsazích Fe $(0.004$ $0.023 \mathrm{apfu}), \mathrm{Zr}(0-0.009 \mathrm{apfu}), \mathrm{Nb}(0.001-0.010 \mathrm{apfu})$, Ta (0 - 0.005 apfu), V (0 - 0.002 apfu) a Ca (0.001 - 0.008 $a p f u)$. Druhou formou výskytu rutilu jsou drobné jehličky či nepravidelná zrna, vznikající spolu s chloritem a titanitem na úkor biotitu. Identita rutilu byla potvrzena Ramanovou spektroskopií. V naměřených Ramanových spektrech byly zjištěny pozice hlavních pásů při 611, 447, 236 a 682 $\mathrm{cm}^{-1}$ (řazeno dle klesající relativní intenzity) a dvou slabých pásů při 371 a $145 \mathrm{~cm}^{-1}$; tyto hodnoty odpovídají podle databáze RRUFF rutilu.

Anatas se vyskytuje velmi vzácně, byl zjištěn pouze $v$ jednom vzorku $v$ asociaci s ilmenitem, rutilem, titanitem a pyritem. Vytváří zde samostatná izometrická, hypautomorfně až xenomorfně omezená zrna o velikosti až $90 \mu \mathrm{m}$.
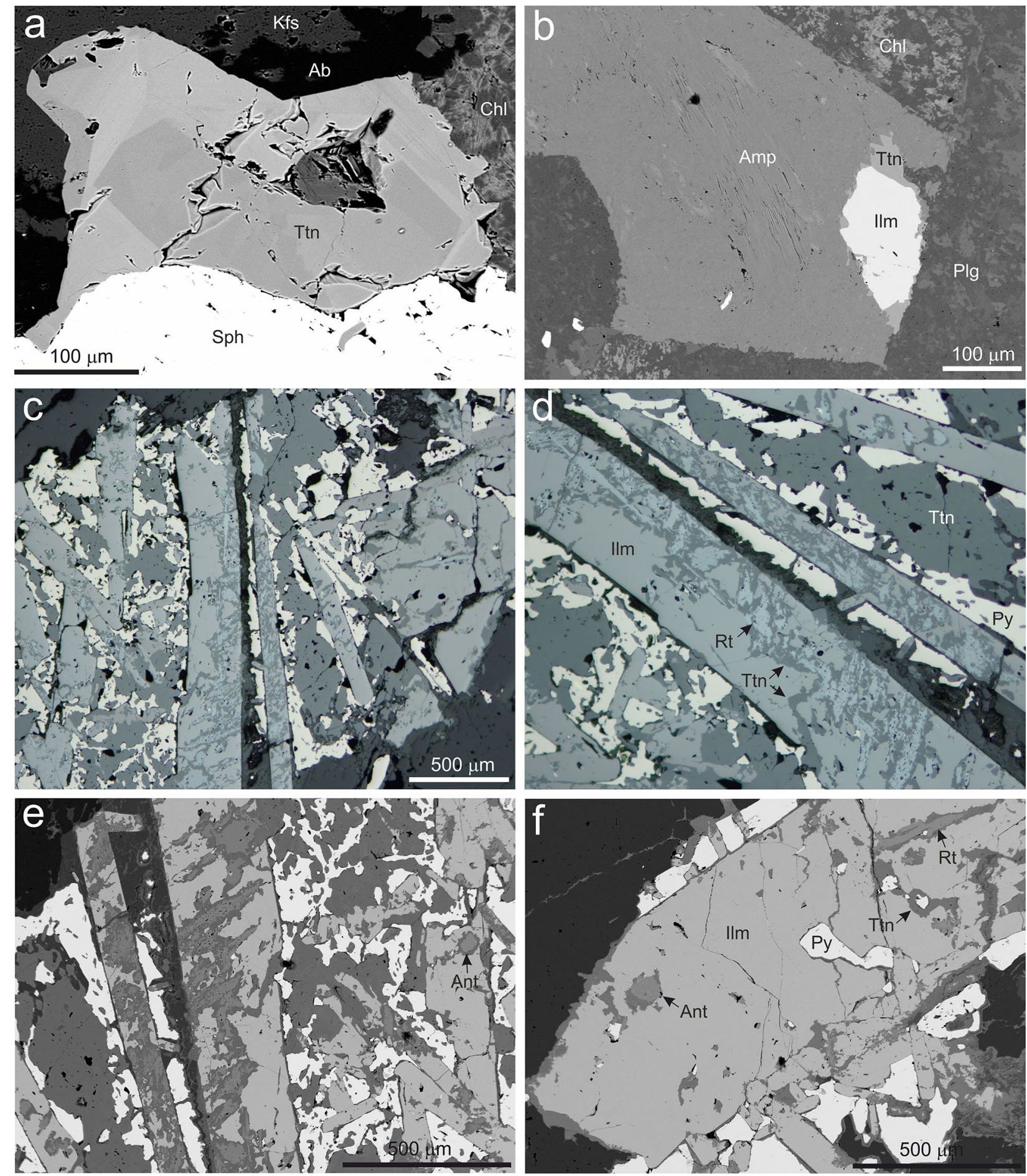

Obr. 6 Minerální asociace a vývin minerálů ze studovaných pegmatitů z lomu Pohled. a - zonální krystal titanitu (Ttn), světlá zóna má zvýšený obsah Sn a Zr. Chl - chlorit, Ab - albit, Kfs - K-živec, Sph - sfalerit. BSE obraz. b - automorfní krystal ilmenitu (IIm), od okrajů zatlačovaný titanitem (Ttn), narostlý v dutině vyplněné později amfibolem (Amp). Plg - plagioklas. BSE obraz. c-f - lišty a izometrická zrna ilmenitu (IIm), částečně zatlačovaného titanitem (Ttn) a obsahujícího inkluze a agregáty rutilu (Rt) a anatasu (Ant). Py-pyrit. Obrázky d-e jsou detaily střední spodní části snímku (c). c,d - odražené polarizované světlo, e,f - BSE snímky. Všechny snímky Z. Dolníček. 
Vystupuje ve zcela analogické pozici jako rutil - tj. v jednotlivých inkluzích, které jsou uzavřeny $v$ alterovaném ilmenitu a lemovány titanitem (obr. 6c-f). Ojediněle byl pozorován i vzájemný kontakt rutilu a anatasu. Od rutilu se dá anatas odlišit podle tvaru, absence porozity a nepatrně tmavšího odstínu v BSE obraze. Nevykazuje žádnou chemickou zonalitu. Bodové analýzy ukázaly jen nízké obsahy Fe (0.001 - 0.003 apfu), Nb (0.001 - 0.002 apfu), Ta (max. $0.001 \mathrm{apfu})$ a Ca (0.002 - $0.005 \mathrm{apfu})$, které jsou $v$ průměru nižší než v rutilu. Naopak vyšší průměrný obsah má v anatasu vanad (0.001 - 0.002 apfu). Identita anatasu byla také potvrzena Ramanovou spektroskopií. $\checkmark$ naměřených Ramanových spektrech byly zjištěny pozice hlavních pásů prì 145, 639, 397 a 516 cm$^{-1}$ (řazeno dle klesající relativní intenzity) a dvou slabých pásů při 198 a $1087 \mathrm{~cm}^{-1}$; tyto hodnoty odpovídají podle databáze RRUFF anatasu.

Granát byl zjištěn v akcesorickém množství jen v jednom vzorku pegmatitu, bohatém na sulfidické minerály (pyrit, sfalerit). Vytváří automorfně omezená izometrická zrna s šestiúhelníkovým průřezem o velikosti max. 90 um. Izolovaná zrna granátu jsou nejčastěji uzavřena v křemeni, K-živci či albitu $\left(A n_{0.1-1.0}\right)$, zcela ojediněle v kalcitu (obr. $4 e, f)$. V BSE obraze obvykle nevykazuje zonálnost, jen ojediněle Ize postřehnout světlejší, neostře omezenou, přechodnou zónu mezi jádrem a okrajem krystalu. Granát je vždy čerstvý, bez známek druhotných přeměn. Chemické složení bylo studováno na několika zrnech pomocí celkem 35 bodových analýz, jejichž výběr je uveden $v$ tabulce 5 . Jde o Ca-granát, často s deficitním obsahem křemíku (2.81 - 3.03 apfu), někdy i slabě zvýšeným obsahem fluoru (max. 0.04 apfu) a nízkou analytickou sumou (95.7 - 99.5 hm. \%). Vzhledem k tomu, že v granátu nebyl analyticky stanoven obsah vody a poměr $\mathrm{Fe}^{2+} / \mathrm{Fe}^{3+}$, není možný jednoznačný rozpočet získaných analýz se zohledněním všech existujících koncových členů (Grew et al. 2013). $Z$ toho důvodu jsme použili modelový prepočet na 5 kationtů v pozicích $X$ a $Y$ (tab. 5). Převažující složkou je ve všech získaných analýzách vždy grosulárová komponenta (obr. $3 g$ ), jejíž obsahy kolísají mezi 35.0 až 46.9

Tabulka 4 Př́klady chemického složení titanitu (Ttn), ilmenitu (IIm), rutilu (Rt) a anatasu (Ant) z pohledských pegmatitů. Obsahy oxidu v hm. \%, hodnoty apfu jsou vypočítány na základ 3 kationtů (titanit), 3 atomů kyslíku (ilmenit), resp. 2 atomů kyslíku (rutil, anatas).

\begin{tabular}{|c|c|c|c|c|c|c|c|c|c|c|c|c|c|c|}
\hline An. č. & 1 & 2 & 3 & 4 & 5 & 6 & 7 & 8 & 9 & 10 & 11 & 12 & 13 & 14 \\
\hline Minerál & Ttn & Ttn & Ttn & Ttn & Ttn & Ttn & $\mathrm{IIm}$ & $\mathrm{IIm}$ & $\mathrm{IIm}$ & $\mathrm{IIm}$ & $\mathrm{Rt}$ & $\mathrm{Rt}$ & $\mathrm{Rt}$ & Ant \\
\hline $\mathrm{Nb}_{2} \mathrm{O}_{5}$ & 0.09 & 0 & 0.31 & 0.11 & 0.18 & 0.77 & 0.11 & 0.11 & 0.29 & 0 & 1.64 & 0.13 & 0.12 & 0.31 \\
\hline $\mathrm{Ta}_{2} \mathrm{O}_{5}$ & 0 & 0 & 0 & 0 & 0 & 0.52 & 0 & 0 & 0 & 0 & 1.33 & 0.14 & 0 & 0.19 \\
\hline $\mathrm{SiO}_{2}{ }^{5}$ & 31.69 & 30.89 & 30.35 & 30.01 & 29.89 & 30.05 & 0 & 0 & 0 & 0 & 0 & 0 & 0 & 0 \\
\hline $\mathrm{TiO}_{2}$ & 24.22 & 35.86 & 34.78 & 36.86 & 36.14 & 35.52 & 52.10 & 51.69 & 52.54 & 51.91 & 94.02 & 97.34 & 98.65 & 98.07 \\
\hline $\mathrm{ZrO}_{2}$ & 0 & 0 & 0.42 & 1.28 & 1.03 & 1.25 & 0.31 & 0 & 0 & 0.24 & 0.61 & 1.20 & 0 & 0 \\
\hline $\mathrm{SnO}_{2}^{2}$ & 0 & 0.08 & 2.19 & 0.82 & 1.78 & 0.5 & 0 & 0 & 0 & 0 & 0 & 0 & 0 & 0 \\
\hline $\mathrm{Al}_{2} \mathrm{O}_{3}$ & 9.78 & 2.58 & 1.20 & 1.12 & 0.98 & 0.47 & 0 & 0 & 0 & 0 & 0 & 0 & 0 & 0 \\
\hline${ }_{2} \mathrm{O}_{3}$ & & & & & & & 0 & 0 & 0 & 0.07 & 0 & 0 & 0 & 0.17 \\
\hline $\mathrm{Sc}_{2} \mathrm{O}_{3}$ & 0.09 & 0 & 0 & 0 & 0.05 & 0 & 0 & 0 & 0 & 0 & 0 & 0 & 0 & 0 \\
\hline $\mathrm{Y}_{2} \mathrm{O}_{3}$ & & & & & & & 0.17 & 0 & 0.24 & 0.23 & 0 & 0 & 0.29 & 0 \\
\hline$-\mathrm{a}_{2} \mathrm{O}_{3}$ & 0.19 & 0.32 & 0.33 & 0.19 & 0 & 0.32 & & & & & & & & \\
\hline $\mathrm{Ce}_{2} \mathrm{O}_{3}$ & 0.14 & 0.21 & 0.17 & 0.24 & 0.23 & 0.25 & & & & & & & & \\
\hline $\mathrm{MgO}$ & 0 & 0 & 0 & 0 & 0 & 0 & 0 & 0 & 0 & 0.27 & 0 & 0 & 0 & 0 \\
\hline $\mathrm{aO}$ & 27.79 & 28.56 & 28.07 & 28.10 & 27.74 & 28.27 & 0 & 0.04 & 0.05 & 0.12 & 0.09 & 0.22 & 0.58 & 0.15 \\
\hline $\mathrm{nO}$ & 0 & 0 & 0 & 0 & 0 & 0 & 3.39 & 4.79 & 6.17 & 36 & 0 & 0 & 0 & 0 \\
\hline $\mathrm{eO}$ & 2.05 & 0.33 & 0.69 & 0.12 & 0.16 & 0.22 & 42.39 & 41.80 & 39.17 & 35.60 & 1.17 & 1.13 & 0.41 & 0.06 \\
\hline & 3.29 & 0.20 & 0.22 & 0.18 & 0.14 & 0.10 & & & & & & & & \\
\hline $\mathrm{O}=\mathrm{F}$ & -1.39 & -0.08 & -0.09 & -0.08 & -0.06 & -0.04 & & & & & & & & \\
\hline Celke & 97.94 & 98.95 & 98.64 & 98.95 & 98.26 & 98.20 & 98.47 & 98.44 & 98.46 & 8.81 & 8.87 & 100.17 & 100.05 & 98.96 \\
\hline $\mathrm{Nb}^{5+}$ & 0.001 & 0 & 0.005 & 0.002 & 0.003 & 0.012 & 0.001 & 0.001 & 0.003 & 0 & 0.010 & 0.001 & 0.001 & 0.002 \\
\hline $\mathrm{Ta}^{5+}$ & 0 & 0 & 0 & 0 & 0 & 0.005 & 0 & 0 & 0 & 0 & 0.005 & 0.001 & 0 & 0.001 \\
\hline $\mathrm{Si}^{4+}$ & 020 & 007 & 1.012 & 996 & 1.002 & 1.009 & 0 & 0 & 0 & 0 & 0 & 0 & 0 & 0 \\
\hline $1^{4}$ & 587 & 0.880 & 0.872 & 0.920 & 0.911 & 0.898 & 1.003 & 997 & 1.008 & 0.995 & 0.970 & 983 & .991 & 0.993 \\
\hline $7 \mathrm{r}^{4+}$ & 0 & 0 & 0.007 & 0.021 & 0.017 & 0.020 & 0.004 & 0 & 0 & 0.003 & 0.004 & 0.008 & 0 & 0 \\
\hline $\mathrm{Sn}^{4+}$ & 0 & 0.001 & 0.029 & 0.011 & 0.024 & 0.007 & 0 & 0 & 0 & 0 & 0 & 0 & 0 & 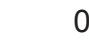 \\
\hline $\mathrm{Al}^{3+}$ & 0.371 & 0.099 & 0.047 & 0.044 & 0.039 & 0.019 & 0 & 0 & 0 & 0 & 0 & 0 & 0 & 0 \\
\hline $\mathrm{V}^{3+}$ & & & & & & & 0 & 0 & 0 & 0.001 & 0 & 0 & 0 & 0.002 \\
\hline $\mathrm{Sc}^{3+}$ & 003 & 0 & 0 & 0 & 0.001 & 0 & & & & & & & & \\
\hline$Y^{3+}$ & & & & & & & 0.002 & 0 & 0.003 & 0.003 & 0 & 0 & 0.002 & 0 \\
\hline $\mathrm{La}^{3+}$ & 002 & 0.004 & 0.004 & 0.002 & 0 & 0.004 & & & & & & & & \\
\hline $\mathrm{Ce}^{3+}$ & 0.002 & 0.003 & 0.002 & 0.003 & 0.003 & 0.003 & & & & & & & & \\
\hline $\mathrm{Mg}^{2+}$ & 0 & 0 & 0 & 0 & 0 & 0 & 0 & 0 & 0 & & 0 & 0 & 0 & 0 \\
\hline $\mathrm{Ca}^{2+}$ & 959 & 0.998 & 1.003 & 0.999 & 0.996 & 1.018 & 0 & 0.001 & 0.001 & 0.003 & 0.001 & 0.003 & 0.008 & 0.002 \\
\hline $\mathrm{Mn}^{2+}$ & 0 & 0 & 0 & 0 & 0 & 0 & 0.073 & 0.104 & 0.133 & 0.224 & 0 & 0 & 0 & 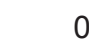 \\
\hline $\mathrm{Fe}^{2+}$ & 55 & 09 & 19 & 0.003 & 0.004 & 0.006 & 0.907 & 0.897 & 0.836 & 0.759 & 0.013 & 0.013 & 0.005 & 0.001 \\
\hline $\mathrm{F}^{-}$ & 0.335 & 0.021 & 0.023 & 0.019 & 0.015 & 0.011 & & & & & & & & \\
\hline Sum & 3.000 & 3.000 & 3.000 & 3.000 & 3.000 & 3.000 & 1.990 & 2.001 & 1.985 & 1.998 & 1.004 & 1.008 & 1.007 & 1.000 \\
\hline
\end{tabular}


mol. \%. Další tři složky se vyskytují v řádově podobných koncentracích. Ve více než polovině získaných analýz je druhou nejzastoupenější složkou složka goldmanitová (celkový zjištěný rozsah 13.0 - 24.5 mol. \%), méně často složka uvarovitová (12.1 - $24.3 \mathrm{~mol}$. \%) a nejméně často složka andraditová (12.4 - 20.0 mol. \%). S velkým odstupem pak následuji složka Ti-granátová (3.7 - 7.3 mol. \%) a spessartinová (0.9 - 1.9 mol. \%). Katoitová složka byla zjištěna asi ve $2 / 3$ naměřených analýz (0.4 - 5.4 mol. \%), zatímco fluorokatoitová složka jen asi ve třetině analýz (0.6 - 1.0 mol. \%). Zcela ojediněle pak byly zjištěny $v$ ma- lých koncentracích i složka pyropová (max. 0.5 mol. \%) a almandinová (max. 0.8 mol. \%). Statisticky významné korelace mezi obsahy jednotlivých složek zpravidla neexistují (srov. obr. 5d); jedinou výjimkou jsou složky grosulárová a katoitová, kde je patrná zřetelná negativní závislost $\left(R^{2}=0.72 ;\right.$ obr. $\left.5 d\right)$. Nebyly vypozorovány ani žádné systematické trendy změn chemismu od středu $\mathrm{k}$ okraji v různých krystalech granátu.

Apatit je poměrně hojnou akcesorií. Jeho izolované, hypautomorfně až automorfně omezené krystaly dosahuji velikosti až $0.2 \mathrm{~mm}$. V nábrusech byly zastiženy jak po-

Tabulka 5 Příklady chemického složení granátu z pohledského pegmatitu. Obsahy oxidů v hm. \%, hodnoty apfu jsou vypočitány na základ 5 kationtů v pozicích $X$ a Y, obsahy koncových členů v mol. \%. * obsah vody dopočítán ze stechiometrie katoitové substituce $\mathrm{SiO}_{4}^{4-}=\square\left(\mathrm{OH}^{-}\right)_{4}$.

\begin{tabular}{|c|c|c|c|c|c|c|c|c|c|c|c|c|c|c|}
\hline An. č. & 1 & 2 & 3 & 4 & 5 & 6 & 7 & 8 & 9 & 10 & 11 & 12 & 13 & 14 \\
\hline $\mathrm{P}_{2} \mathrm{O}_{5}$ & 0 & 0 & 0 & 0.09 & 0 & 0 & 0 & 0 & 0 & 0 & 0 & 0 & 0 & 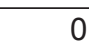 \\
\hline $\mathrm{SiO}_{2}{ }^{\circ}$ & 37.75 & 37.24 & 36.99 & 37.16 & 37.13 & 36.74 & 36.30 & 36.06 & 35.71 & 35.23 & 35.10 & 35.11 & 34.81 & 34.70 \\
\hline $\mathrm{TiO}_{2}^{2}$ & 1.25 & 1.51 & 2.38 & 1.96 & 1.62 & 1.21 & 1.34 & 1.25 & 1.65 & 1.50 & 1.64 & 1.57 & 1.74 & 1.66 \\
\hline $\mathrm{Al}_{2} \mathrm{O}_{3}$ & 10.21 & 9.88 & 9.15 & 9.16 & 9.04 & 9.18 & 9.00 & 9.73 & 9.35 & 9.13 & 9.35 & 9.22 & 8.95 & 9.08 \\
\hline $\mathrm{V}_{2} \mathrm{O}_{3}$ & 5.55 & 4.78 & 5.74 & 5.66 & 4.18 & 4.00 & 4.96 & 7.70 & 6.08 & 5.05 & 6.40 & 6.47 & 6.43 & 7.06 \\
\hline $\mathrm{Cr}_{2} \mathrm{O}_{3}$ & 4.44 & 4.68 & 4.50 & 4.76 & 7.31 & 7.61 & 4.76 & 3.86 & 5.41 & 5.44 & 4.38 & 5.15 & 5.26 & 4.62 \\
\hline $\mathrm{Fe}_{2} \mathrm{O}_{3}$ & 5.29 & 5.99 & 4.97 & 5.27 & 4.60 & 4.82 & 6.52 & 4.68 & 4.21 & 5.64 & 5.15 & 4.08 & 4.06 & 4.54 \\
\hline $\mathrm{MgO}$ & 0 & 0.04 & 0 & 0.12 & 0 & 0 & 0 & 0 & 0 & 0 & 0.11 & 0 & 0 & 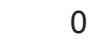 \\
\hline $\mathrm{CaO}$ & .40 & 34.38 & 33.50 & 33.62 & 34.02 & 33.83 & 34.01 & 4.49 & 4.07 & 3.81 & 33.58 & 34.37 & 3.76 & 33.85 \\
\hline $\mathrm{nO}$ & 59 & 0.60 & 0.57 & 0.60 & 0.79 & 82 & 58 & 0.42 & & & & 62 & 56 & 0.56 \\
\hline $\mathrm{FeO}$ & 03 & 0 & 0.06 & 0.12 & 0 & 0 & 0 & 0.02 & 0 & 0.01 & 0.16 & 0 & .01 & 0.35 \\
\hline $\mathrm{ZnO}$ & 0 & 0 & 0 & 0 & 0 & 0 & 0 & 0.55 & 0 & 0 & 0.26 & 0 & 0 & \\
\hline $\mathrm{Na}_{2} \mathrm{O}$ & 0 & 06 & 16 & 0 & 07 & 15 & 0 & 0 & 16 & 0 & & 06 & & 0 \\
\hline $\mathrm{H}_{2} \mathrm{O}^{*}$ & 0 & 0.10 & 0 & 0 & 0 & 0.21 & 0.25 & 1.00 & 0.86 & 92 & 19 & 1.20 & .12 & 1.40 \\
\hline $\mathrm{F}$ & 0 & 0 & 0 & 0 & 0 & 0 & 0 & 0.11 & 0.16 & 0 & 0 & 10 & 0 & .16 \\
\hline Celke & .51 & 99.26 & 3.02 & 98.52 & 98.76 & 98.57 & 97.72 & 9.87 & 3.25 & .38 & 97.94 & 7.95 & 6.83 & 97.98 \\
\hline $\mathrm{P}^{5+}$ & 0 & 0 & 0 & .006 & 0 & 0 & 0 & 0 & 0 & 0 & 0 & 0 & 0 & 0 \\
\hline $\mathrm{Si}^{4+}$ & 030 & 2.987 & 3.021 & 3.029 & 3.008 & 2.972 & 2.966 & 867 & 884 & 75 & 39 & 38 & & 811 \\
\hline$\square$ & 0 & 0.013 & 0 & 0 & 0 & 0.028 & 0.034 & 33 & & & & & & 0.189 \\
\hline$T \mathrm{su}$ & 30 & 0 & 021 & 035 & 8 & & 3.000 & 00 & 00 & & & & & 00 \\
\hline $\mathrm{Ti}^{4+}$ & 75 & 091 & 46 & 120 & 99 & 74 & 082 & 0.075 & 0 & 92 & & 95 & & 101 \\
\hline $\mathrm{Al}^{3+}$ & & 34 & 1 & 880 & 33 & $0 . \varepsilon$ & 7 & & & & & & & \\
\hline $\mathrm{V}^{3+}$ & 57 & 07 & 76 & 370 & 72 & 0.259 & 25 & & & & & & & 59 \\
\hline $\mathrm{Cr}^{3+}$ & 82 & 97 & 291 & 307 & 88 & 87 & & & & & & & & .296 \\
\hline $\mathrm{Fe}^{3+}$ & 19 & & 05 & 323 & 0.280 & 0.293 & 401 & 280 & 56 & 46 & & 48 & 50 & .277 \\
\hline $\mathrm{Mg}^{2+}$ & 0 & 5 & 0 & 015 & 0 & 0 & 0 & 0 & 0 & 0 & & 0 & 0 & 0 \\
\hline $\mathrm{Mn}^{2+}$ & & 041 & & 041 & 54 & 56 & 040 & & 40 & 45 & & 42 & 39 & 38 \\
\hline $\mathrm{Fe}^{2}$ & & 0 & & 008 & 0 & 0 & 0 & & 0 & 0 & & 0 & 0 & 24 \\
\hline $\mathrm{Ca}^{2+}$ & 58 & 54 & 32 & 36 & 53 & 32 & 77 & 38 & 49 & 57 & & 977 & 59 & 938 \\
\hline $7 n^{2+}$ & 0 & 0 & 0 & 0 & 0 & 0 & 0 & 0.032 & 0 & 0 & & 0 & 0 & \\
\hline $\mathrm{Na}^{+}$ & 0 & & & 0 & & & 0 & 0 & & 0 & & & & 0 \\
\hline$X+Y$ & 000 & 5.000 & 5.000 & .000 & 5.000 & 5.000 & 000 & 5.000 & 5.000 & 5.000 & 000 & 00 & .000 & 5.000 \\
\hline $\mathrm{F}^{-}$ & 0 & 0 & 0 & 0 & 0 & 0 & 0 & 0.028 & 0.041 & 0 & 0 & 0.026 & 0 & 0.041 \\
\hline $\mathrm{OH}^{-}$ & 0 & 0.053 & 0 & 0 & 0 & 0.113 & 0.136 & 0.530 & 0.463 & 0.501 & 0.642 & 0.647 & 0.611 & 0.756 \\
\hline $\mathrm{Ti}-\mathrm{Gr}$ & 3.8 & 5 & 3 & 0 & .9 & 3.7 & 4.1 & 7 & 0 & 4.6 & 0 & 8 & 5.4 & 5.1 \\
\hline Grs & .9 & & & 41.9 & & & & & & .2 & .2 & .1 & 5.7 & 35.0 \\
\hline Gol & & & & 18.5 & & & & & & & .8 & .0 & .1 & 22.9 \\
\hline Uva & & 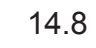 & 5 & 15.3 & 4 & 3 & & 1 & 3 & 6 & 14.0 & .5 & .0 & 14.8 \\
\hline And & 16.0 & 18.1 & 15.3 & 16.2 & 14.0 & 14.7 & 20.0 & 14.0 & 12.8 & 17.3 & 15.7 & 12.4 & 12.5 & 13.8 \\
\hline Sps & & & 1.3 & 1. & 1 & 1.9 & 1.3 & 0.9 & 1.3 & 1.5 & 1.2 & 1.4 & 1.3 & 1.3 \\
\hline Alm & .1 & 0 & 0.1 & 3 & 0.0 & 0.0 & 0.0 & 0.0 & 0.0 & 0.0 & 0.4 & 0.0 & 0.0 & 0.8 \\
\hline Prp & 0 & 0.2 & 0 & 0.5 & 0 & 0 & 0 & 0 & 0 & 0 & 0.4 & 0 & 0 & c \\
\hline$F-K a$ & 0 & 0 & 0 & 0 & 0 & 0 & 0 & .7 & 1.0 & 0 & 0 & 0.6 & 0 & 1.0 \\
\hline Kat & 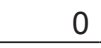 & 0.4 & 0 & 0 & 0 & .9 & 1.1 & 3.7 & 2.8 & 4.2 & 5.4 & 4.7 & 5.1 & 5.3 \\
\hline Celkem & 100.0 & 99.5 & 100.0 & 100.0 & 99.1 & 99.4 & 99.1 & 100.0 & 99.3 & 99.9 & 100.0 & 98.5 & 99.1 & 100.0 \\
\hline
\end{tabular}


délné prizmatické řezy obdélníkového tvaru (někdy př́ičně rozlomené), tak i řezy podle báze s charakteristickým šestiúhelníkovým obrysem. Z uvedeného Ize usuzovat, že morfologicky jsou krystaly apatitu velmi jednoduché spojky základního prizmatu a báze. Orientační WDS analýzy $(n=11)$ ukázaly, že ve strukturní pozici vápníku jsou př́tomny jen nepatrně zvýšené koncentrace $\mathrm{Fe}$ (max. $0.25 \mathrm{hm}$. \% FeO) a Mn (max. $0.37 \mathrm{hm}$. \% MnO). Obsah fosforu odpovídá 2.993 až 3.003 apfu $\mathrm{P}$, takže nelze uvažovat o přítomnosti většího množství uhlíku. Obsah fluoru kolísá mezi 0.41 a 0.87 apfu a v některých zrnech byly zjištěny i zvýšené obsahy $\mathrm{Cl}$ (max. $0.10 \mathrm{apfu}$; tab. 6). Provedené analýzy tedy nasvědčují př́tomnosti 41.0 - 87.4 mol. \% fluorapatitové, 0.0 - 10.2 mol. \% chlorapatitové a 10.0 - 51.7 mol. \% hydroxylapatitové komponenty. Klasifikačně tedy odpovídají studované apatity fluorapatitu až hydroxylapatitu (obr. 3e).

Prehnit je akcesorickou fází, která se vyskytuje spolu s klinozoisitem v okolí alterovaných plagioklasů. Vytváří drobná nepravidelná zrna a výplně tenkých žilek. Prehnit je mladší než chlorit (obr. 7c). Chemické složení prehnitu je celkem jednoduché, vedle $\mathrm{Ca}, \mathrm{Al}$ a Si byly orientačními WDS analýzami (tab. 7) zjištěny zvýšené obsahy Fe (0.028 - $0.179 a p f u)$ a většinou i hořčíku (max. 0.041 apfu) a fluoru (max. $0.045 \mathrm{apfu}$ ).
Klinozoisit byl zjištěn jen velmi sporadicky. Vytváří většinou drobná, xenomorfně omezená zrna v asociaci se sekundárním chloritem a prehnitem $\vee$ blízkosti alterovaných bazičtějších plagioklasů. Sedm WDS analýz (výběr je uveden $v$ tab. 7) ukázalo převahu složky klinozoisitové nad epidotovou a piemontitovou $\left(\mathrm{CzO}_{51.9-94.0}\right.$ $\left.\mathrm{Ep}_{5.1-48.1} \mathrm{Pie}_{0.0-1.5}\right)$; viz obr. 3d). V klasifikačním pojetí Franze a Liebschera (2004) a Armbrustera et al. (2006) jde tedy ve všech prípadech o klinozoisit. Minoritními komponentami klinozoisitu jsou fluor (0.03 - 0.07 apfu) a ve čtyřech prípadech i hořčík (0.04 - 0.11 apfu).

Allanit-(Ce) byl zjištěn jen velmi vzácně, zatím byla nalezena pouze tř̆i zrna o velikosti maximálně $3 \mathrm{~mm}$, zarostlá v živci. Zrna jsou makroskopicky černá, smolně lesklá a mají lasturnatý lom (obr. 7a). V BSE obraze je větší část jednoho blíže studovaného zrna allanitu kompozičně homogenní, u okrajů a podél trhlin je však místy patrná prítomnost alterovaných partií (All 2 a All 3 na obr. 7b), které se vyznačují tmavšími odstíny v porovnání s nealterovaným allanitem (All 1 na obr. $7 b$ ).

Chemické složení allanitu bylo studováno prostřednictvím 17 bodových WDS analýz, jejichž reprezentativní výběr je uveden $v$ tabulce 8 . Nealterovaný allanit má nejnižší a zároveň stechiometrický obsah Si (2.99 - 3.02 apfu), obsahy REE + Y mezi 0.81 a 0.83 apfu, obsahy
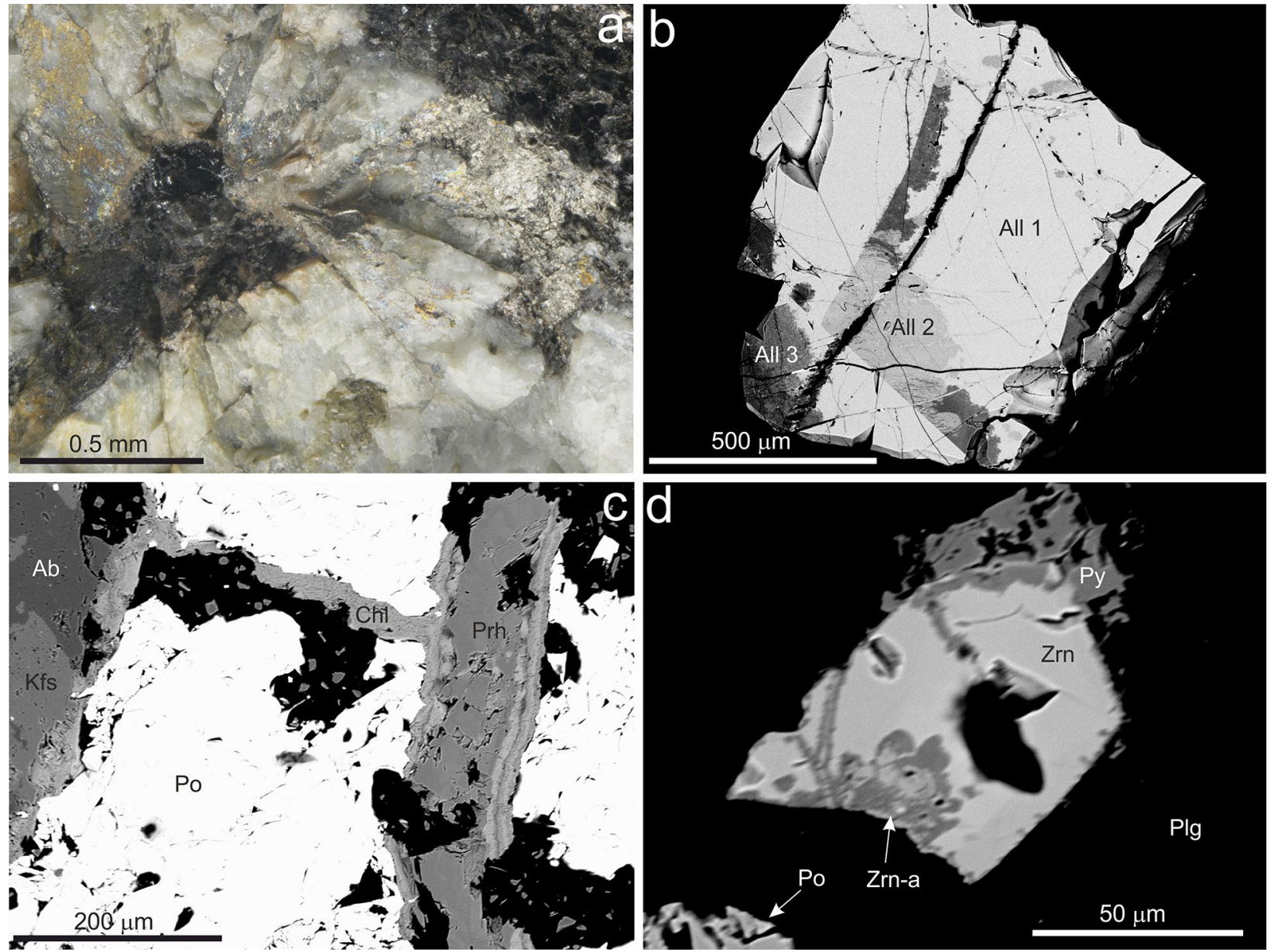

Obr. 7 Minerální asociace a vývin minerálů ze studovaných pegmatitů z lomu Pohled. a - makrofoto zrna allanitu zarostlého na styku živců a biotitu. V pravém horním rohu je zachycen kontakt pegmatitu s okolním amfibolitem. Vlasové žilky v celém vzorku jsou tvořeny pyritem. $b$ - zonální allanit v BSE obraze: nejsvětlejší jsou nealterované partie (All 1), tmavší jsou alterované partie (All 2 a All 3). c - zonální hydrotermální žilka $v$ silně alterovaném a zrudnělém pegmatitu. Na okraji žilky je přitomen chlorit (Chl), ve středu prehnit (Prh). Po - pyrhotin, Ab - albit, Kfs - K-živec. BSE obraz. d - krystal nezonálního zirkonu (Zrn), ve spodní části s tmavší alterovanou partií (Zrn-a). Plg - plagioklas, Po - pyrhotin, Py - pyrit. BSE obraz. Všechny snímky Z. Dolníček a J. Ulmanová. 
Al mezi 1.96 a 1.98 apfu a nejvyšší zjištěné obsahy $\mathrm{Fe}$ (0.83 - 0.85 apfu), Mg (0.17 - 0.18 apfu) a Ca (1.12 - 1.13 apfu). Obsah Mn se pohybuje kolem 0.02 - 0.03 apfu a obsah Th okolo 0.03 apfu. Nealterované allanity mají také nejvyšší analytické sumy (92.3 - 92.9 hm. \%). Vzhledem $\mathrm{k}$ převaze Ce $\mathrm{v}$ rámci sumy $\mathrm{REE}+\mathrm{Y}$ jde tedy klasifikačně o allanity-(Ce). $V$ obraze BSE tmavší alterované partie se vždy vyznačují zvýšenými obsahy Si (3.22 - 3.72 apfu), sníženými analytickými sumami (85.4 - 89.0 hm. \%) a nižšími obsahy $\mathrm{Fe}, \mathrm{Mg}$ a $\mathrm{Ca}$ (tab. 8). Obsahy REE $+\mathrm{Y}$ jsou $\checkmark$ porovnání $s$ nealterovaným allanitem rozdílné $v$ různě alterovaných partiích (obr. 3c): mírně vyšší (0.85 - 0.94 $a p f u$ ) $\vee$ méně alterovaných partí́ch (All 2 na obr. $7 \mathrm{~b}$ ) a nižší (0.59 - $0.78 a p f u)$ ve více alterovaných partiích (All 3 na obr. $7 b)$.

Chondritem normalizované distribuce prvků vzácných zemin se vyznačuji velmi podobným průběhem $v$ případě všech analyzovaných allanitů (obr. 8). Nealterované allanity mají $v$ průměru nepatrně více frakcionované $\mathrm{REE}\left(\mathrm{La}_{\mathrm{N}} / \mathrm{Sm}_{\mathrm{N}}=4.45-5.19\right)$ než alterované allanity $\left(\mathrm{La}_{\mathrm{N}} /\right.$ $\left.\mathrm{Sm}_{\mathrm{N}}=3.65-4.66\right)$. Ce anomálie $\mathrm{v}$ allanitech bud' chybí nebo je nevýrazná $\left(\mathrm{Ce} / \mathrm{Ce}^{*}=0.98-1.12\right)$. Eu anomálie má poněkud více variabilní charakter: $v$ nealterovaných allanitech je patrná slabě pozitivní Eu anomálie (Eu/Eu* = 1.09 - 1.34), zatímco $v$ alterovaných allanitech Eu anomálie bud' chybí nebo je ještě slaběji pozitivní $\left(E u / E u^{*}=\right.$ 1.00 až 1.24$)$, zcela ojediněle i slabě negativní $\left(E u / E u^{*}=\right.$ 0.88 ; obr. 8).

Zirkon je akcesorickým minerálem, jehož automorfně až hypautomorfně omezené krystaly izometrického až krátce sloupečkovitého habitu jsou uzavírány nejčastěji $v$ živcích a biotitu. Dosahují velikosti maximálně $60 \mu \mathrm{m}$. V BSE obraze vykazují někdy oscilační růstovou zonalitu, ale byly zjištěny i nezonální individua (obr. 7d). Orientační bodové analýzy ( $\mathrm{n}=7$; tab. 9) nealterovaných zirkonů ukázaly vedle $\mathrm{Zr}$ a Si i průběžně zvýšené obsahy $\mathrm{P}(0.04$ $0.11 \mathrm{apfu}), \mathrm{Hf}$ (0.009 - $0.020 \mathrm{apfu}), \mathrm{U}(0.001-0.017 \mathrm{apfu})$, $\mathrm{Sr}(0.003-0.007 \mathrm{apfu})$ a Fe (0.003 - $0.018 \mathrm{apfu})$. Ojediněle byly pozorovány výraznější projevy alterace a hydratace zirkonu (v BSE obraze tmavé partie v okolí prasklin, obr. 7d) se sníženými analytickými sumami a porušenou stechiometrií. $V$ alterovaných (metamiktizovaných?) partiích byly mikrosondovými analýzami $(n=3)$ někdy zjištěny i výrazněji vyšší obsahy Fe (až 0.05 apfu) a U (max. 0.027 apfu) a také zvýšené obsahy Ca (až 0.09 apfu), Al (až 0.02 apfu) a Mn (max. 0.01 apfu).

Kalcit se místy ojediněle vyskytuje jako nejmladší výplň korozních dutin. Nasedá na starší hydrotermální fáze, reprezentované zejména chloritem a pyritem (obr. 4f). $\checkmark$ EDS spektrech kalcitu nebyly zjištěny žádné příměsi.

\section{Diskuse}

\section{Geneze zjištěných minerálů}

Provedené mineralogické studium pegmatitů z lomu Pohled ukázalo, že jde o horniny, jejichž minerální složení bylo silně ovlivněno postmagmatickými hydrotermálními procesy. Jen menší část zjištěných minerálních fází vznikla prímou krystalizací z pegmatitové taveniny. Do této skupiny můžeme počítat větší část křemene (srůstajícího se živci), K-živec (o jeho magmatogenním pưvodu jasně svědčí přitomnost perthitických odmíšenin), plagioklas, biotit, apatit, zirkon a allanit. Vedle texturních charakteristik nasvědčuje magmatickému původu mnohých z výše jmenovaných fází i jejich chemické složení - zvýšený podíl albitové složky $v$ některých K-živcích, zvýšený obsah anortitové komponenty $v$ plagioklasech, zvýšené obsahy $\mathrm{Th} \vee$ allanitu, Ti $\vee$ biotitu a Hf a $U \vee$ zirkonu. Na druhé straně můžeme vyčlenit skupinu prokazatelně mladších hydrotermálních minerálů, které zpravidla zatlačuji starší minerální fáze nebo vyplňují korozní dutiny či žilky. Sem patří zejména chlorit, prehnit, klinozoisit, titanit, kalcit a amfibol a křemen amfibolových hnízd a žilek. Interpretace hydrotermálního původu amfibolu je na zájmové lokalitě podporována i výskytem agregátů chemicky analogického amfibolu v žilách alpského typu (Z. Dolníček, nepublikovaná data).

Problematické geneze jsou zbývající minerální fáze - ilmenit, rutil, anatas a granát. IImenit svou pozicí a vývinem budí dojem fáze vzniklé krystalizací z pegmatitové taveniny. Na druhé straně je však třeba upozornit na skutečnost, že se chemické složení studovaného ilmenitu z pegmatitů nijak neliší od nepochybně hydrotermálních ilmenitů, které jsou na zájmové lokalitě přítomny na žilách alpského typu a také na rudních žilách (Z. Dolníček, nepublikovaná data). To by nasvědčovalo jeho hydrotermálnímu původu. Rutil a anatas vytvářejí inkluze v ilmenitu, nikdy nebyly zjištěny mimo ilmenit. Takové texturní uspořádání lze interpretovat bud' jako starší (nebo stejně staré) uzavřeniny $\mathrm{TiO}_{2}$ fází nebo jako produkt mladších alterací ilmenitu. $V$ této souvislosti je důležitá okolnost, že $\mathrm{TiO}_{2}$ minerály jsou prítomny $v$ asociaci $s$ ilmenitem pouze $\vee$ těch prípadech, kdy je $\vee$ minerální asociaci př́tomen i pyrit. Naprosto stejná situace byla zaznamenána i při studiu alpských žil z lomu Pohled (Z. Dolníček, nepublikovaná data). Zdá se tedy pravděpodobné, že vznik $\mathrm{TiO}_{2}$ fází je vedlejším produktem sulfurizace ilmenitu, kdy v prostředí bohatém na redukovanou síru ale chudém na

Tabulka 6 Př́klady chemického složení apatitu z pohledských pegmatitù. Obsahy oxidù v hm. \%, hodnoty apfu jsou vypočítány na základ 12 atomủ kyslíku a $1(\mathrm{OH}+\mathrm{Cl}+\mathrm{F})$. Obsahy koncových členů v mol. \%. * - obsah vody dopočten ze stechiometrie.

\begin{tabular}{lrrrrrr}
\hline An. č. & 1 & 2 & 3 & 4 & 5 & 6 \\
\hline $\mathrm{P}_{2} \mathrm{O}_{5}$ & 43.36 & 42.10 & 42.77 & 42.38 & 42.27 & 42.34 \\
$\mathrm{Al}_{2} \mathrm{O}_{3}$ & 0 & 0.06 & 0 & 0 & 0 & 0 \\
$\mathrm{CaO}$ & 56.71 & 55.22 & 56.38 & 55.62 & 55.66 & 55.44 \\
$\mathrm{MnO}$ & 0.37 & 0.23 & 0 & 0 & 0 & 0.19 \\
$\mathrm{FeO}$ & 0.11 & 0.12 & 0 & 0.09 & 0.10 & 0.25 \\
$\mathrm{H}_{2} \mathrm{O}^{*}$ & 0.18 & 0.32 & 0.44 & 0.69 & 0.87 & 0.92 \\
$\mathrm{~F}$ & 3.38 & 3.00 & 2.88 & 2.22 & 1.55 & 1.55 \\
$\mathrm{Cl}$ & 0.19 & 0.17 & 0 & 0.20 & 0.72 & 0.53 \\
$\mathrm{O}=\mathrm{F}+\mathrm{Cl}$ & -1.47 & -1.30 & -1.21 & -0.98 & -0.82 & -0.77 \\
\hline $\mathrm{Celkem}$ & 102.83 & 99.92 & 101.26 & 100.22 & 100.35 & 100.45 \\
\hline $\mathrm{P}^{5+}$ & 3.000 & 2.997 & 2.999 & 3.003 & 2.999 & 2.999 \\
$\mathrm{Al}^{3+}$ & 0 & 0.006 & 0 & 0 & 0 & 0 \\
$\mathrm{Ca}^{2+}$ & 4.966 & 4.974 & 5.003 & 4.987 & 4.997 & 4.970 \\
$\mathrm{Mn}^{2+}$ & 0.026 & 0.016 & 0 & 0 & 0 & 0.013 \\
$\mathrm{Fe}^{2+}$ & 0.008 & 0.008 & 0 & 0.006 & 0.007 & 0.017 \\
\hline $\mathrm{Suma} \mathrm{kat.}^{2+}$ & 7.999 & 8.002 & 8.002 & 7.996 & 8.002 & 8.001 \\
\hline $\mathrm{F}^{-}$ & 0.874 & 0.798 & 0.754 & 0.588 & 0.411 & 0.410 \\
$\mathrm{Cl}^{-}$ & 0.026 & 0.024 & 0 & 0.028 & 0.102 & 0.075 \\
$\mathrm{OH}$ & 0.100 & 0.178 & 0.246 & 0.384 & 0.487 & 0.515 \\
\hline Suma an. & 1.000 & 1.000 & 1.000 & 1.000 & 1.000 & 1.000 \\
\hline $\mathrm{F}^{-}$-apt & 87.4 & 79.8 & 75.4 & 58.8 & 41.1 & 41.0 \\
$\mathrm{Cl}_{-}-\mathrm{apt}$ & 2.6 & 2.4 & 0 & 2.8 & 10.2 & 7.5 \\
$\mathrm{OH}-$-apt & 10.0 & 17.8 & 24.6 & 38.4 & 48.7 & 51.5 \\
\hline $\mathrm{Celkem}^{-}$ & 100 & 100 & 100 & 100 & 100 & 100 \\
\hline & & & & & &
\end{tabular}


železo vznikal pyrit na úkor ilmenitu coby zdroje železa, zatímco pro reakci nepotřebný $\mathrm{TiO}_{2}$ zůstával "na místě“ $\checkmark$ podobě samostatné minerální fáze. Jde tedy o proces v zásadě analogický sulfurizaci Fe-bohatého chloritu (Alonso-Azcárate et al. 1999). Přeměnu schematicky vyjadřuje rovnice:

$2 \mathrm{FeTiO}_{3}+4 \mathrm{H}_{2} \mathrm{~S}+\mathrm{O}_{2} \rightarrow 2 \mathrm{FeS}_{2}+2 \mathrm{TiO}_{2}+4 \mathrm{H}_{2} \mathrm{O}$

Stejně tak diskutabilní je paragenetická príslušnost granátu. Charakter jeho výskytu je většinou (vyjma zcela ojedinělé asociace $s$ kalcitem, obr. 4f) kompatibilní s představou krystalizace z pegmatitové taveniny. Granát je $v$ pegmatitech obecně vcelku běžnou akcesorií, která má typicky almandin-spessartinové složení (např. London 2008). Obsahy vápníku bývají někdy zvýšené v okrajových zónách granátů z kontaminovaných pegmatitů, i tak ale jeho obsahy obvykle nepřevyšuji 40 at. \% (Gadas 2012, Buriánek et al. 2017). Přítomnost granátu, $v$ němž je vápník $v$ dané strukturní pozici naprosto dominantním kationtem (> 98 at. \%; tab. 5), je tak v prostředí granitických pegmatitů zcela unikátní. Grosulárový granát popisují z leukotonalitového pegmatitu u Rudy nad Moravou Novák, Gadas (2010) a Gadas et al. (2013). Autoři předpokládají vznik tohoto granátu z taveniny. Tato interpretace je v souladu s vysokým obsahem Ca v celém pegmatitu, dokumentovaným mj. i prítomností anortitovou komponentou bohatých magmatických plagioklasů $\left(\mathrm{An}_{28-}\right.$ 97; Novák, Gadas 2010; Gadas 2012). V našem případě Ize naopak konstatovat diametrální rozdíl mezi složením pegmatitu a granátu - ve vzorku obsahujícím granát od-

Tabulka 7 Príklady chemického složení klinozoisitu (Clz) a prehnitu (Prh) z pohledských pegmatitu. Obsahy oxidů $\mathrm{v} \mathrm{hm}$. \%, hodnoty apfu jsou vypočítány na základ 8 kationtů (klinozoisit), resp. 10 atomů kyslíku a $2(\mathrm{OH}+\mathrm{F})$ (prehnit). * - obsah vody dopočten ze stechiometrie. Obsahy koncových členů v mol. \%.

\begin{tabular}{|c|c|c|c|c|c|c|}
\hline $\begin{array}{l}\text { An. č. } \\
\text { Fáze }\end{array}$ & $\begin{array}{l}1 \\
\mathrm{Clz}\end{array}$ & $\begin{array}{l}2 \\
\mathrm{Clz}\end{array}$ & $\begin{array}{l}3 \\
\mathrm{Clz}\end{array}$ & $\begin{array}{l}4 \\
\mathrm{Clz}\end{array}$ & $\begin{array}{l}5 \\
\text { Prh }\end{array}$ & $\begin{array}{l}6 \\
\text { Prh }\end{array}$ \\
\hline $\mathrm{SiO}_{2}$ & 39.17 & 38.16 & 38.53 & 38.47 & 44.00 & 42.10 \\
\hline $\mathrm{Al}_{2} \mathrm{O}_{3}$ & 32.85 & 30.41 & 29.03 & 27.20 & 23.56 & 21.06 \\
\hline $\mathrm{Mn}_{2} \mathrm{O}_{3}$ & 0.15 & 0 & 0 & 0 & 0 & 0 \\
\hline $\mathrm{Fe}_{2} \mathrm{O}_{3}$ & 0.90 & 2.02 & 4.47 & 7.90 & 1.06 & 3.32 \\
\hline $\mathrm{MgO}$ & 0 & 0.43 & 0 & 0.38 & 0.40 & 0 \\
\hline $\mathrm{CaO}$ & 24.42 & 23.79 & 24.09 & 24.10 & 26.69 & 26.53 \\
\hline $\mathrm{Na}_{2} \mathrm{O}$ & 0 & 0.08 & 0 & 0 & 0.09 & 0 \\
\hline $\mathrm{H}_{2} \mathrm{O}^{*}$ & 1.86 & 1.82 & 1.78 & 1.84 & 4.36 & 4.09 \\
\hline $\mathrm{F}$ & 0.22 & 0.17 & 0.27 & 0.17 & 0 & 0.20 \\
\hline $\mathrm{O}=\mathrm{F}$ & -0.09 & -0.07 & -0.11 & -0.07 & 0 & -0.08 \\
\hline Celkem & 99.48 & 96.81 & 98.05 & 99.99 & 100.16 & 97.22 \\
\hline $\mathrm{Si}^{4+}$ & 2.988 & 2.998 & 3.024 & 2.992 & 3.023 & 3.015 \\
\hline $\mathrm{Al}^{3+}$ & 2.954 & 2.816 & 2.686 & 2.493 & 1.908 & 1.778 \\
\hline $\mathrm{Mn}^{3+}$ & 0.010 & 0 & 0 & 0 & 0 & 0 \\
\hline $\mathrm{Fe}^{3+}$ & 0.052 & 0.120 & 0.264 & 0.462 & 0.055 & 0.179 \\
\hline $\mathrm{Mg}^{2+}$ & 0 & 0.050 & 0 & 0.044 & 0.041 & 0 \\
\hline $\mathrm{Ca}^{2+}$ & 1.996 & 2.003 & 2.026 & 2.008 & 1.965 & 2.036 \\
\hline $\mathrm{Na}^{+}$ & 0 & 0.012 & 0 & 0 & 0.012 & 0 \\
\hline Suma kat. & 8.000 & 8.000 & 8.000 & 8.000 & 7.002 & 7.007 \\
\hline $\mathrm{F}^{-}$ & 0.053 & 0.042 & 0.067 & 0.042 & 0 & 0.045 \\
\hline $\mathrm{OH}^{-}$ & 0.947 & 0.957 & 0.932 & 0.957 & 1.997 & 1.953 \\
\hline Suma an. & 1.000 & 0.999 & 0.999 & 0.999 & 1.997 & 1.999 \\
\hline $\mathrm{Clz}$ & 94.0 & 87.3 & 72.2 & 51.9 & & \\
\hline Pie & 1.0 & 0.0 & 0.0 & 0.0 & & \\
\hline Epi & 5.1 & 12.7 & 27.8 & 48.1 & & \\
\hline
\end{tabular}

povídá chemické složení plagioklasu prakticky čistému albitu $\left(A n_{0.1-1.0}\right)$. Další indicie protiřečící magmatickému pưvodu granátu vyplývá z porovnání chemického složení granátu a dalších $v$ pegmatitu prítomných potenciálně kogenetických tmavých minerálů, které jsou schopny do své struktury pojmout vedle železa i další tranzitní kovy. Granát je značně (na poměry obvyklé v granitických pegmatitech možno říci až extrémně) bohatý chromem (4.4 - $\left.7.6 \mathrm{hm} . \% \mathrm{Cr}_{2} \mathrm{O}_{3}\right)$ a vanadem $\left(4.0-7.7 \mathrm{hm} . \% \mathrm{~V}_{2} \mathrm{O}_{3}\right)$, zatímco nepochybně magmatogenní biotit a allanit mají obsahy $\mathrm{Cr}$ a $\vee$ nesrovnatelně nižší (max. $0.1 \mathrm{hm}$. \% oxidů obou prvků v biotitech, max. $0.29 \mathrm{hm} . \% \mathrm{~V}_{2} \mathrm{O}_{3}$ v allanitu; chrom $v$ allanitu je vždy pod mezí stanovitelnosti, srov. tab. 2 a 8). Z uvedeného vyplývá, že granát v pohledském pegmatitu s největší pravděpodobností také není magmatogenního původu, ale že vznikal až během následného postmagmatického vývoje, tedy krystalizací z hydrotermálních fluid. Hydrotermální či hydrotermálně-metasomatický původ grosulárového, uvarovitového i goldmanitového granátu je naprosto běžný, popisovaný z řady geologických situací (např. Mueller, Delor 1991; Deer et al. 1997; Uher et al. 2008, 2015; Dolníček, Krobot 2013; Schreier et al. 2013). Přesvědčivým dokladem mobility chromu a vanadu během rané fáze hydrotermální aktivity je na námi studované lokalitě i nově zjištěná přítomnost spinelidů s vysokým obsahem $\mathrm{Cr}$ a Zn a zvýšeným obsahem $\mathrm{V}$ ve výplni rudní žily s kyzovým $\mathrm{Zn}-\mathrm{Pb}$ zrudněním (Z. Dolníček, nepublikovaná data).

\section{Magmatický vývoj}

Chemické složení většiny zjištěných magmatogenních minerálů nevybočuje $z$ mezí obvyklých pro žulové pegmatity. Výjimkou je však chemické složení biotitu, jenž klasifikačně spadá k flogopitu (obr. 3h). Flogopit je typický naopak pro vysoce hořečnaté horniny typu ultrabazik či metakarbonátů (Fleet 2003). Vysoký poměr $\mathrm{Mg} / \mathrm{Fe}$ v biotitu je pro granitické pegmatity neobvyklý a Ize ho v dané situaci nejsnáze vysvětlit kontaminací taveniny metamorfovanými horninami moldanubika $s$ vysokým obsahem Mg. V př́mé prostorové asociaci se v pohledském lomu běžně vyskytují amfibolity a vzácně také serpentinity. Kontaminaci pegmatitové taveniny okolními horninami na studované lokalitě zdůrazňují i Welser a Záruba (2004).

Zajímavé je také chemické složení apatitu. Apatit představuje minerální fázi, která je citlivým indikátorem obsahu fluoru v minerogenetickém prostředí, nebot' tento prvek je při krystalizaci apatitu výrazně upřednostňován před Cl či OH (např. Kropáč et al. 2012). Skutečnost, že přibližně třetina získaných analýz apatitu patří klasifikačně hydroxylapatitu (obr. 3e), jasně ukazuje na nízký obsah $\mathrm{F} v$ pegmatitové tavenině.

Allanit-(Ce) je jediným zjištěným koncentrátorem prvků vzácných zemin (REE). Má málo frakcionované REE $\left(\mathrm{La}_{N} / \mathrm{Sm}_{N}=3.65-5.19\right)$, a to i v porovnání s hydrotermálními allanity $z$ alpských žil $z$ této lokality $\left(\mathrm{La}_{\mathrm{N}} / \mathrm{Sm}_{\mathrm{N}}=1.65\right.$ - 10.86; Mastíková 2011; Dolníček, nepublikovaná data) či s allanity z křemenné žily od Vrbčan v kutnohorském krystaliniku $\left(\mathrm{La}_{N} / \mathrm{Sm}_{\mathrm{N}}=2.04\right.$ - 4.98; Dolníček, Ulmanová 2019). Nízký stupeň frakcionace REE nasvědčuje nízkému obsahu silných REE-komplexujících ligandů v minerálotvorném prostředí (zejména fluoridových aniontů). Slabě pozitivní Eu anomálie $\left(E u / E^{*}=1.09\right.$ - 1.34) nealterovaných allanitů nasvědčuje zvýšení Eh minerálotvorného prostředí, což je konzistentní již se samotnou přítomností allanitu s obsahem $\mathrm{Fe}^{3+}$ (Watanabe et al. 2016). 
Ke zvýšení Eh mohlo dojít interakcí pegmatitové taveniny například s vodnými fluidy s vyšším Eh (Lee et al. 2003) nebo $\mathrm{s}$ horninami, obsahujícími $\mathrm{Fe}^{3+}$ ( $v$ dané geologické situaci mohlo jít např. o amfibolity). Přítomnost zvýšené koncentrace $\mathrm{Fe}^{3+}$ je indikována jak $\mathrm{z}$ nábojové bilance získaných analýz nealterovaných allanitů (tab. 8), tak z pozice projekčních bodů analýz v diagramu Petríka et al. (1995; obr. 3c). $\checkmark$ prostoru pohledského lomu jsou pegmatity přítomny pouze $\vee$ metamorfitech, nikdy př́mo $v$ tělese pohledské žuly. Je tedy možné, že pưvod pegmatitové taveniny přímo nesouvisel s procesy frakční krystalizace pohledské žuly, ale spíše s anatexí okolních moldanubických metamorfitů, k níž mohlo dojít při intruzi tělesa pohledské žuly. Tomu by mohla odpovídat i zjištěná texturní, minerální a geochemická primitivnost pohledských pegmatitů.

Tabulka 8 Př́klady chemického složení allanitu z pohledského pegmatitu. Obsahy oxidů v hm. \%, hodnoty apfu jsou vypočitány na základ 12.5 atomů kyslíku a sumu kationtů $=8.000$. a - alterovaná fáze, $R E Y=R E E+Y$.

\begin{tabular}{|c|c|c|c|c|c|c|c|c|c|c|c|c|c|c|}
\hline An. č. & 1 & 2 & 3 & 4 & 5 & $6 a$ & $7 a$ & $8 a$ & $9 a$ & $10 a$ & $11 a$ & $12 a$ & $13 a$ & $14 a$ \\
\hline $\mathrm{SiO}_{2}$ & 0.31 & 9.78 & 9.95 & 0.14 & 0.29 & 1.45 & 1.14 & 1.10 & 1.60 & 2.14 & 4.04 & 3.94 & 37.92 & 38.72 \\
\hline $\mathrm{O}_{2}$ & 0 & 0 & 0 & 0 & 0 & 0 & 0 & 0 & 0 & 0 & 0 & 0 & 0.13 & 0.11 \\
\hline $\mathrm{rO}_{2}$ & 0 & 0 & 0 & 0 & 0 & 0 & $v$ & 0 & 0 & 0.14 & 0 & 0.07 & 0 & \\
\hline $\mathrm{hO}_{2}^{2}$ & 1.31 & 1.36 & 1.43 & 1.41 & 1.55 & 1.81 & 1.51 & 1.60 & 1.59 & 1.65 & 1.19 & 1.31 & 1.45 & 1.35 \\
\hline $\mathrm{Al}_{2} \mathrm{O}_{3}$ & 16.69 & 16.70 & 16.78 & 16.64 & 16.68 & 14.67 & 15.53 & 15.71 & 14.75 & 15.26 & 17.03 & 16.96 & 16.70 & 16.83 \\
\hline & 0.18 & 0.14 & 0.15 & 0.12 & 0.15 & 0.16 & 0.18 & 0.13 & 0.11 & 0.20 & 0.15 & 0.15 & 0.17 & 0.18 \\
\hline $\mathrm{n}_{2} \mathrm{O}_{3}$ & 0.34 & 0.34 & 0.36 & 0.28 & 0.32 & 0.17 & 0.23 & 0.19 & 0.17 & 0.14 & 0.28 & 0.27 & .23 & 0.19 \\
\hline $\mathrm{Fe}_{2} \mathrm{O}_{3}$ & 0.73 & 1.32 & 1.27 & 0.84 & 0.74 & 0 & 0 & 0 & 0 & 0 & 0 & 0 & 0 & 0 \\
\hline $\mathrm{Y}_{2} \mathrm{O}_{3}$ & 0.63 & 0.71 & 0.61 & 0.51 & 0.54 & 0.72 & 0.72 & 0.75 & 0.75 & 0.91 & 0.56 & 0.71 & 0.64 & 0.61 \\
\hline $\mathrm{La}_{2} \mathrm{O}_{3}$ & 5.00 & 4.99 & 5.14 & 5.08 & 4.99 & 4.97 & 4.78 & 5.02 & 5.02 & 4.90 & 4.64 & 4.59 & 3.74 & 3.75 \\
\hline $\mathrm{Ce}_{2} \mathrm{O}_{3}$ & 10.30 & 0.20 & 10.30 & 9.97 & 10.21 & 11.16 & 10.22 & 10.65 & 11.07 & 11.11 & 9.58 & 9.72 & 8.33 & 7.85 \\
\hline $\mathrm{Pr}_{2} \mathrm{O}_{3}$ & 1.16 & 1.24 & 1.18 & 1.17 & 1.21 & 1.30 & 1.17 & 1.28 & 1.29 & 1.22 & 0.99 & 1.08 & 0.99 & 0.92 \\
\hline $\mathrm{Nd}_{2}^{2} \mathrm{O}_{3}$ & 3.88 & 3.80 & 3.79 & 3.84 & 3.74 & 4.08 & 3.68 & 4.01 & 4.24 & 4.16 & 3.48 & 3.54 & 3.03 & 3.21 \\
\hline $\mathrm{Sm}_{2} \mathrm{O}_{3}$ & 0.65 & 0.64 & 0.72 & 0.61 & 0.63 & 0.70 & 0.74 & 0.73 & 0.79 & 0.83 & 0.62 & 0.64 & 0.63 & 0.62 \\
\hline $\mathrm{Eu}_{2} \mathrm{O}_{3}$ & 0.23 & 0.24 & 0.23 & 0.23 & 0.20 & 0.24 & 0.22 & 0.22 & 0.21 & 0.19 & 0.20 & 0.21 & 0.21 & 0.16 \\
\hline $\mathrm{Gd}_{2}^{2} \mathrm{O}_{3}^{3}$ & 0.48 & 0.48 & 0.38 & 0.47 & 0.49 & 0.63 & 0.56 & 0.53 & 0.46 & 0.52 & 0.39 & 0.48 & .42 & 0.38 \\
\hline $\mathrm{Dy}_{2} \mathrm{O}_{3}$ & 0 & 0 & 0 & 0.17 & 0.15 & 0.17 & 0.19 & 0.20 & 0 & 0.21 & 0.18 & 0.14 & 0.14 & 0.22 \\
\hline $\mathrm{gO}$ & 18 & 1.17 & 1.14 & 1.16 & 1.21 & 0.64 & 0.7 & 0.84 & & 0.63 & 0.68 & 0.68 & 1 & 0.52 \\
\hline 10 & & & & & & & & & & & & & & .95 \\
\hline $\mathrm{O}$ & 34 & 79 & 99 & .27 & 23 & 6.62 & 7 & 7 & 7 & 6.86 & 5.85 & 5.85 & .23 & 4.39 \\
\hline $\mathrm{Na}_{2} \mathrm{O}$ & 0 & 0 & 0 & 0 & 0 & 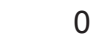 & & 0 & & & & & & \\
\hline $\mathrm{K}_{2} \mathrm{O}$ & 0 & 0 & 0 & 0 & 0 & 0 & 0 & 0 & 0 & & 10 & 11 & 11 & 12 \\
\hline Celk & .90 & .37 & .91 & 33 & 87 & 61 & .66 & .96 & 11 & .00 & .44 & 7.83 & 6.41 & 87.08 \\
\hline $4^{4+}$ & 22 & 91 & 992 & 24 & 23 & 347 & 247 & 221 & 2 & 317 & 413 & 104 & 89 & .716 \\
\hline & 0 & 0 & 0 & 0 & 0 & 0 & 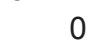 & 0 & 0 & 0 & 0 & 0 & 10 & .008 \\
\hline $4+$ & 0 & 0 & 0 & 0 & 0 & 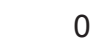 & & & 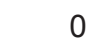 & & $v$ & & 0 & \\
\hline $4+$ & & & & & & & & & & & & 30 & & 029 \\
\hline & & & & & & & & & & & & & & 904 \\
\hline V & & & & & & & & & & & & & 11 & 011 \\
\hline 3 & & & & & & & & & & 11 & 21 & 21 & 17 & 014 \\
\hline & & & & & & 0 & 0 & 0 & 0 & 0 & 0 & . & 0 & \\
\hline & & & 32 & 7 & & & & & & & & & & 31 \\
\hline $\mathrm{La}^{3+}$ & & & & & & & & & & & & & & 133 \\
\hline $\mathrm{Ce}^{3+}$ & & & & & & & & & & & & & 97 & .276 \\
\hline $\mathrm{Pr}^{3+}$ & 2 & 5 & & 3 & 4 & & 4 & 8 & & 16 & 36 & 39 & 35 & .032 \\
\hline & & & & & & & & & & & & & & .110 \\
\hline & & & & & & & & & & & & & & .020 \\
\hline $\mathrm{Eu}^{3-}$ & & 88 & 8 & 8 & & 9 & & & & 7 & 7 & 07 & 07 & 005 \\
\hline & & 16 & & & & & & & & & & & & 012 \\
\hline & 0 & 0 & 0 & & & & & & & & & & 04 & .007 \\
\hline $\mathrm{Mg}^{2+}$ & & & & & & & & & & 97 & 2 & & 74 & .074 \\
\hline & & & & & & & & & & & & & 712 & .715 \\
\hline & & 38 & & 78 & 71 & 39 & 42 & 51 & & & & 91 & 344 & .352 \\
\hline & 0 & 0 & . & 0 & 0 & & & 0 & & 0 & & 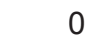 & 0 & \\
\hline $\mathrm{K}^{+}$ & 0 & 0 & 0 & 0 & 0 & 0 & 0 & 0 & 0 & 0 & 0.013 & 0.014 & 0.014 & 0.015 \\
\hline Sum & 00 & 00 & 00 & & & & 07 & 15 & 61 & 7.725 & 7.659 & 7.652 & 7.468 & 7.465 \\
\hline REYtot & 0.820 & 0.826 & & & & & & & & & & & 0.650 & 0.626 \\
\hline & 4.76 & 4.84 & 4.45 & 5.19 & 4.92 & 4.37 & 4.01 & 4.28 & 3.92 & 3.67 & 4.66 & 4.45 & 3.69 & 3.77 \\
\hline & & & & & & & & 1. & 1. & 0.88 & 1.24 & 1.15 & 1.24 & 1.00 \\
\hline $\mathrm{e} / \mathrm{C}$ & 03 & 98 & .00 & .98 & 1.00 & 1.05 & 1.04 & 1.01 & 1.04 & 1.09 & 1.07 & 1.05 & 1.04 & 1.01 \\
\hline
\end{tabular}




\section{Hydrotermální vývoj}

Zjištěná pestrá asociace minerálů hydrotermálního původu $\vee$ pohledských pegmatitech nasvědčuje dlouhodobé hydrotermální aktivitě, která byla provázena změnami chemického složení pưsobících fluid i jejich teploty. Nejstarším produktem postmagmatických alteračních procesů je pravděpodobně granát. Soudíme tak s ohledem na absenci dalších hydrotermálních fází (amfiboly, chlority, apod.) v těsné asociaci s tímto minerálem, což může indikovat, že granát $v$ době, kdy tyto další fáze vznikaly, již nebyl stabilní. S tímto názorem koresponduje i skutečnost, že pouze nejstarší partie agregátů/krystalů zmíněných amfibolů a chloritů mají zvýšené obsahy $\mathrm{V} a$ $\mathrm{Cr}$, což Ize interpretovat bud' ve smyslu vyznívání prítoku fluid bohatých na tyto prvky nebo jako důsledek alterace části V-Cr bohatých granátů při změněných podmínkách (pokles teploty?) pokračující hydrotermální aktivity. Naopak nejmladšími alteračními fázemi jsou mladší generace chloritu (s príměsí smektitu), prehnit a kalcit.

Identifikace prítomnosti dvou chemicky odlišných generací chloritu je zajímavá v kontextu dosud publikovaných údajů, které naopak pro pohledské chlority indikují uniformní složení. Práce Mastíkové (2011) uvádí bližší informace o chloritech z pohledských alpských žil, rudních žil a okolních rul. $V$ těchto prípadech se vždy jednalo o trioktaedrické chlority klinochlor-chamositové řady s relativně úzkým rozsahem chemického složení, které klasifikačně odpovídají zejména klinochloru, ojediněle i chamositu (obr. 3b). Jejich chemické složení je tedy blízké námi zjištěné starší generaci chloritu, liší se jen mírným posunem k nižším hodnotám Si (obr. 3b). Shodným rysem je i nízký obsah Ca a lokálně slabě zvýšené obsahy $\checkmark$ a Cr. To ukazuje na vznik za velmi podobných podmínek. Výpočet teploty krystalizace pomocí chloritové geotermometrie s kalibrací podle Cathelineau (1988) poskytl poněkud vyšší hodnoty $\left(330-373^{\circ} \mathrm{C}\right)$ pro data Mastíkové (2011), zatímco pro starší generaci chloritu z pohledských pegmatitů vycházejí teploty v intervalu $239-329$ ${ }^{\circ} \mathrm{C}$. Pro mladší generaci chloritu z pohledských pegmatitů, očištěnou o analýzy s vysokým obsahem smektitové komponenty, pro něž vycházejí až nereálně nízké hodnoty (viz tab. 3), byly vypočítány teploty ještě nižší, mezi 246 a $68{ }^{\circ} \mathrm{C}$ (tab. 3). To ilustruje na dané lokalitě dlouhodobý kontinuální vznik chloritu z cirkulujících fluid během postupného chladnutí horninového prostředí.

Vznik Ca-granátu, Ca-amfibolu, prehnitu, klinozoisitu, titanitu a kalcitu během naložených hydrotermálních alterací ilustruje vysokou aktivitu vápníku $v$ alteračních fluidech. S ohledem na minerální složení a chemismus magmatogenních fází pohledských pegmatitů je zřejmé, že samotný pegmatit nemohl být výhradním zdrojem tohoto prvku, takže je třeba předpokládat jeho významný přínos $z$ vnějšku. To nasvědčuje otevřené cirkulaci fluid podél puklin, která zahrnovala i další, vápníkem bohatší, členy horninové sekvence $v$ zájmové oblasti. Zdrojem vápníku mohly být zejména amfibolity, které jsou v těsné prostorové asociaci s námi studovanými pegmatity. Otevřenou otázkou zůstává původ dalších „exotických“ prvků, které se uplatnily v hydrotermálním stádiu - chromu a vanadu. Oba elementy se uplatňují hlavně v nejranějších fázích magmatického procesu, takže jejich koncentrace bývají zvýšené $v$ bazických a ultrabazických horninách či jejich metamorfních ekvivalentech. Jejich možným zdrojem na studované lokalitě mohou být tedy amfibolity (které jsou na lokalitě poměrně hojné) nebo serpentinity (na lokalitě velmi vzácné). $V$ případě vanadu Ize snad potenciálně uvažovat i zdroj v grafitických kvarcitech, které bývají v moldanubiku tímto prvkem obohaceny (např. Houzar 1995); v prostoru studované lokality výskyt těchto hornin však zatím zaznamenán nebyl. Grafitické metasedimentární horniny mohou být $v$ některých prípadech obohaceny vanadem i chromem a často jsou tyto litotypy interpretovány jako zdroj kovů pro tvorbu V-Cr bohatých granátů (Černý et al. 1995; Uher et al. 2008, 2015; Feneyrol et al. 2013).

Hydrotermální aktivita se projevila i alterací zirkonu a allanitu. Zajímavý charakter má alterace allanitu, kde Ize v diagramu Petríka et al. (1995; obr. 3c) z pohledu změn chemického složení vysledovat dva trendy. První skupina analýz alterovaných allanitů, získaných z nejtmavších (v obraze BSE) lemů kolem vnějších okrajů zrna (All 3 na obr. 7b) se vyznačuje nižšími obsahy REE a také hliníku $v$ porovnání se složením nealterované části krystalu (trend I na obr. 3c). To je trend typický pro naloženou hyd-
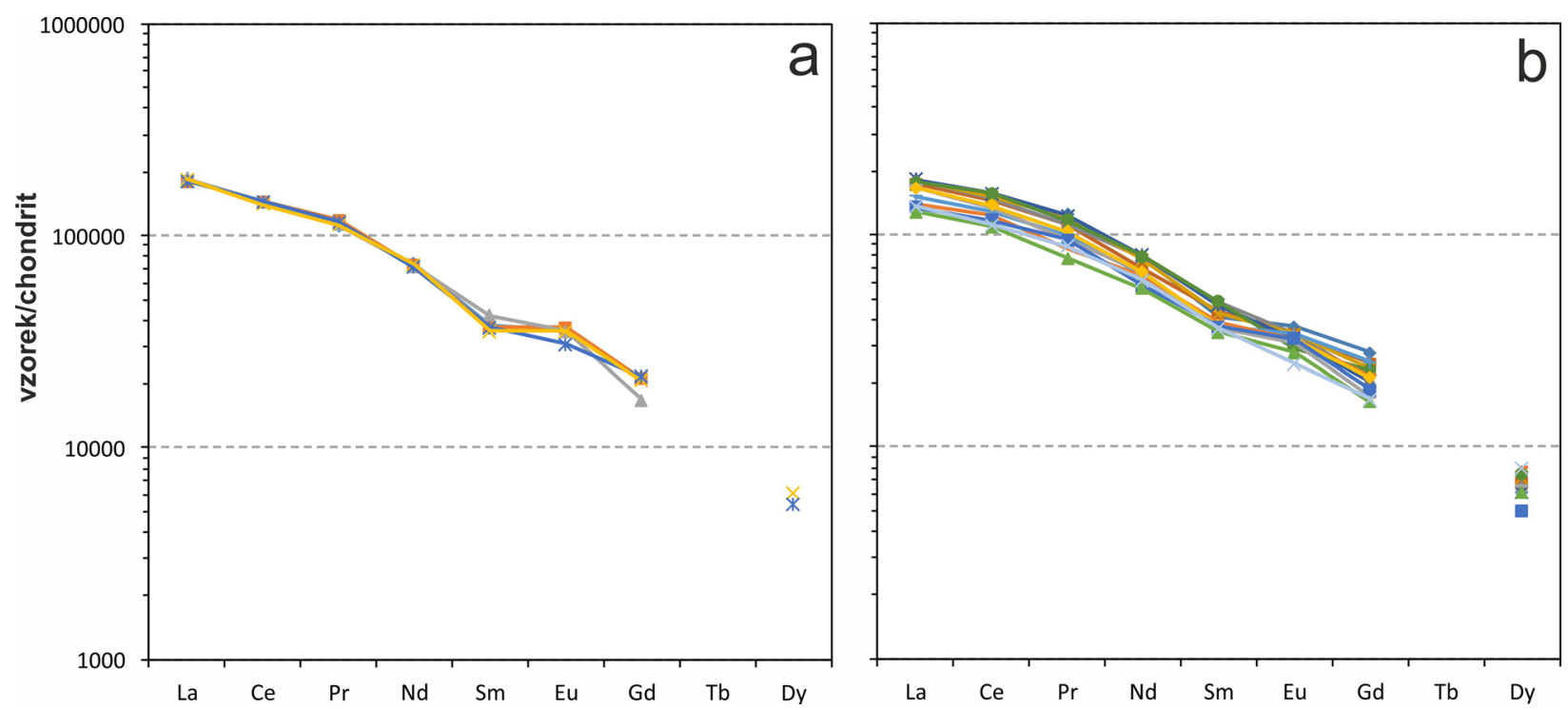

Obr. 8 Chondritem normalizované distribuce prvků vzácných zemin v allanitech z pohledských pegmatitů. a - nealterované allanity. $b$ - alterované allanity. 
rotermální alteraci, při níž dochází k odnosu REE (srov. Wood, Ricketts 2000; Filip et al. 2002; Čopjaková, Škoda 2006; Dolníček, Ulmanová 2019). Naproti tomu trend II, identifikovaný u zbylé části analýz, pocházející z poněkud méně tmavé ( $v$ obraze BSE) středové části studovaného allanitu (All 2 na obr. 7b), by nasvědčoval naopak nárůstu obsahu REE v allanitu během alterace, což však není pravděpodobné. Uvedenou středovou partii zrna proto interpretujeme jako alterovanou růstovou zónu (případně sektor), která byla již primárně výrazně bohatší na REE $v$ porovnání $s$ vnější částí krystalu. $V$ souladu $s$ touto interpretací by byla i existence ostré prímé hranice mezi oběma zmiňovanými kompozičními typy allanitu (obr. 7b).

\section{Porovnání s podobnými pegmatity}

V oblasti moldanubika Českého masivu byla popsána a v řadě prípadů i mineralogicky podrobněji prostudována řada výskytů anatektických kontaminovaných pegmatitů, které jsou blízké námi studovanému výskytu. Většina náleží mineralogicky relativně málo pestrým pegmatitům s jednoduchou vnitřní stavbou, které jsou uloženy v serpentinitech, mramorech, amfibolitech či skarnech. Lokalit je v literatuře popisována celá řada, $z$ významnějších či podrobněji moderněji prostudovaných Ize zmínit např. Vlastějovice, Mirošov, Vevčice, Rešice, Domanínek, či Novou Ves u Oslavan (Němec 1963; Novák 2005; Prokop et al. 2013; Novák et al. 2013; Gadas et al. 2014; Buriánek et al. 2017). Kontaminace pegmatitové taveniny okolními horninami se projevila př́nosem $\mathrm{Ca}$ a/nebo Mg do taveniny, provázená vznikem plagioklasů s vyšší bazicitou (albity až andezíny) než má v pegmatitech jinak obvyklý albit, amfibolů, někdy i pyroxenů, biotitu, titanitu a minerálů epidotové skupiny (epidot, klinozoisit, allanit). Amfiboly vznikající v magmatickém stádiu mají složení hastingsitu, ferohastingsitu, edenitu či magneziohornblendu, tmavé slídy náleží annitu či flogopitu (Novák 2005; Prokop et al. 2013; Novák et al. 2013; Gadas et al. 2014; Buriánek et al. 2017). Tyto pegmatity často obsahují turmalín (dravit, skoryl, uvit, feruvit; Prokop et al. 2013; Novák et al. 2013; Gadas et al. 2014), ale řídké nejsou ani typy bez turmalínu (Novák 2005; Buriánek et al. 2017). Akcesorie jsou zastoupeny apatitem, zirkonem, ilmenitem, někdy i magnetitem, monazitem, xenotimem a granátem (almandin-spessartin, výjimečně se zvýšenou grosulárovou a/nebo andraditovou komponentou; Novák et al. 2013; Buriánek et al. 2017). Časté je, zejména $v$ tělesech lokalizovaných $v$ serpentinitech, mladší ovlivnění nerostné asociace hydrotermálními alteracemi za vyloužení křemene a vzniku aktinolitu, chloritu, prehnitu, skapolitu, jílových minerálů, fluoritu, karbonátů, Ca,REEfluorokarbonátů a zeolitů (Novák 2005; Prokop et al. 2013). Vzácné jsou výskyty rudních minerálů, zejména pyritu, arzenopyritu, výjimečně i ryzího bismutu a slitin Sb-As (Gadas et al. 2014).

Z uvedeného přehledu vyplývá, že námi studované pohledské pegmatity jsou texturně, mineralogicky i geochemicky jednoduché pegmatity, kontaminované zejména $\mathrm{Ca}$ a Mg. $\mathrm{V}$ porovnání s ostatními výskyty je v pohledském pegmatitu výjimečně vysoké uplatnění $\mathrm{Cr}$ a $\mathrm{V}$, a to i v porovnání s pegmatity situovanými v serpentinitech (Novák, Gadas 2010). Studovaný výskyt se také vyznačuje nízkým obsahem fluoru a velmi nízkým obsahem boru. Pohledské pegmatity byly navíc velmi silně postiženy postmagmatickými hydrotermálními přeměnami, spojenými i s významným prínosem rudních prvků a síry.

\section{Závěr}

Pegmatity vytvářejí v lomu Pohled pravé žíly či nepravidelná tělesa tmelící brekcii hostitelských metamorfitů (pararul, amfibolitů) monotónní skupiny moldanubika. Vyznačují se velmi jednoduchou texturní stavbou i jednoduchým minerálním složením, které však bylo místy značně modifikováno naloženými hydrotermálními alteracemi a místy také rudním prínosem. Magmatogenního původu jsou K-živce, plagioklasy $\left(A n_{0-38}\right)$, biotit (flogopit), apatit (fluorapatit až hydroxylapatit), zirkon, allanit a část křemene. Produktem hydrotermálních alterací jsou druhá část křemene, Fe-Mg chlority (starší - klinochlor, mladší - chamosit s príměsí Ca-smektitu), prehnit, klinozoisit, amfibol (aktinolit), titanit, kalcit a velmi pravděpodobně také ilmenit (s max. 22.5 mol. \% pyrofanitové složky), rutil, anatas a grosulárový granát $\left(\mathrm{Grs}_{35-47} \mathrm{Gol}_{13-25} \mathrm{Uva}_{12-24} \mathrm{And}_{12-20}\right.$ Ti-grt ${ }_{4-7} \mathrm{Sps}_{1-2} \mathrm{Kat}_{0-5} \mathrm{~F}_{-} \mathrm{kat}_{0-1} \mathrm{Alm}_{0-1}$ ). Zvýšené obsahy Mg, $\mathrm{Ca}, \mathrm{V}$ a Cr v minerálech pohledských pegmatitů souvisejí s látkovou kontaminací okolními metamorfity (zejména amfibolity a serpentinity a možná také i grafitickými horninami), $\mathrm{k}$ níž docházelo $v$ různé míře jak ve stadiu magmatickém, tak také $v$ následném stadiu hydrotermálním. Geochemicky se jedná o málo frakcionované pegmatity, jejichž vznik patrně souvisel zejména $s$ anatexí hostitelských metamorfitů moldanubika, k níž došlo pravděpodobně v souvislosti s vmístěním bezprostředně sousedícího tělesa pohledské žuly.

Tabulka 9 Příklady chemického složení zirkonu z pohledských pegmatitů. Obsahy oxidů $v \mathrm{hm}$. \%, hodnoty apfu jsou vypočitány na základ 4 atomů kyslíku. a - alterovaná fáze.

\begin{tabular}{lrrrrrr}
\hline An. č. & 1 & 2 & 3 & 4 & $5-a$ & $6-a$ \\
\hline $\mathrm{P}_{2} \mathrm{O}_{5}$ & 1.53 & 2.97 & 1.90 & 3.87 & 2.03 & 3.59 \\
$\mathrm{SiO}_{2}$ & 30.05 & 30.32 & 29.33 & 28.64 & 28.54 & 24.43 \\
$\mathrm{ZrO}_{2}$ & 62.35 & 64.21 & 64.20 & 60.28 & 56.98 & 50.72 \\
$\mathrm{HfO}_{2}$ & 1.00 & 1.41 & 2.25 & 1.86 & 1.58 & 1.98 \\
$\mathrm{UO}_{2}$ & 1.97 & 0.17 & 0.43 & 2.30 & 1.16 & 3.48 \\
$\mathrm{Al}_{2} \mathrm{O}_{3}$ & 0 & 0 & 0 & 0 & 0.44 & 0 \\
$\mathrm{Sc}_{2} \mathrm{O}_{3}$ & 0.14 & 0.09 & 0 & 0 & 0.14 & 0 \\
$\mathrm{CaO}$ & 0 & 0 & 0 & 0 & 1.30 & 2.43 \\
$\mathrm{SrO}_{\mathrm{MnO}}$ & 0.21 & 0.38 & 0.23 & 0.29 & 0.21 & 0.19 \\
$\mathrm{FeO}$ & 0 & 0 & 0 & 0 & 0.24 & 0.18 \\
$\mathrm{~K}_{2} \mathrm{O}$ & 0.54 & 0.57 & 0.19 & 0.16 & 0.61 & 1.62 \\
\hline $\mathrm{Celkem}$ & 0 & 0 & 0 & 0 & 0.09 & 0.06 \\
\hline $\mathrm{P}^{5+}$ & 0.041 & 0.077 & 0.051 & 0.103 & 0.057 & 0.108 \\
$\mathrm{Si}^{4+}$ & 0.951 & 0.924 & 0.923 & 0.905 & 0.939 & 0.866 \\
\hline $\mathrm{Suma}^{4}$ & 0.992 & 1.001 & 0.974 & 1.008 & 0.995 & 0.973 \\
\hline $\mathrm{Zr}^{4+}$ & 0.963 & 0.954 & 0.986 & 0.928 & 0.914 & 0.877 \\
$\mathrm{Hf}^{4+}$ & 0.009 & 0.012 & 0.020 & 0.017 & 0.015 & 0.020 \\
$\mathrm{U}^{4+}$ & 0.014 & 0.001 & 0.003 & 0.016 & 0.008 & 0.027 \\
$\mathrm{Al}^{3+}$ & 0 & 0 & 0 & 0 & 0.017 & 0 \\
$\mathrm{Sc}^{3+}$ & 0.004 & 0.002 & 0 & 0 & 0.004 & 0 \\
$\mathrm{Ca}^{2+}$ & 0 & 0 & 0 & 0 & 0.046 & 0.092 \\
$\mathrm{Sr}^{2+}$ & 0.004 & 0.007 & 0.004 & 0.005 & 0.004 & 0.004 \\
$\mathrm{Mn}^{2+}$ & 0 & 0 & 0 & 0 & 0.007 & 0.005 \\
$\mathrm{Fe}^{2+}$ & 0.014 & 0.015 & 0.005 & 0.004 & 0.017 & 0.048 \\
$\mathrm{~K}^{+}$ & 0 & 0 & 0 & 0 & 0.004 & 0.003 \\
\hline $\mathrm{Suma}^{2+}$ & 1.007 & 0.991 & 1.018 & 0.971 & 1.035 & 1.076 \\
\hline & & & & & &
\end{tabular}




\section{Poděkování}

Práce na článku byly finančně podpořeny Ministerstvem kultury ČR $v$ rámci institucionálního financování výzkumné organizace Národní muzeum (00023272 - cíl DKRVO 1.I.b). Recenzentům M. Novákovi a P. Uherovi děkujeme za četné pripomínky, které významně přispěly $k$ vylepšení rukopisu.

\section{Literatura}

Alonso-Azcárate J, Rodas M, Bottrell SH, Raiswell R, VELASCO F, MAS JR (1999) Pathways and distances of fluid flow during low-grade metamorphism: evidence from pyrite deposits of the Cameros Basin, Spain. J Metamorph Geol 17: 339-348

Anders E, Grevesse N (1989) Abundances of the elements: Meteoritic and solar. Geochim Cosmochim Acta 53: 197-214

Armbruster T, Bonazzi P, Akasaka M, Bermanec V, Chopin C, Gieré R, Heuss-Assbichler S, Liebscher A, MenCHETTI S, PAN Y, PASERO M (2006) Recommended nomenclature of epidote-group minerals. Eur J Mineral 18: $551-567$

BAYLISS P (1975) Nomenclature of the trioctahedral chlorites. Can Mineral 13:178-180

BENEŠ K (1963) Vysvětlivky k přehledné geologické mapě ČSSR 1:200 000, list M-33-XXII. ČGÚ Praha

BERNARD JH (1981) Minerály rudonosných hydrotermálních procesů. In Bernard JH, ČECH F, DÁvidová Š, Dudek A, Fediuk F, Hovorka D, Kettner R, Koděra M, Kopecký L, Němec D, Paděra K, Petránek J, Sekanina J, STANĚK J, Šímová M: Mineralogie Československa: 186-405. Academia Praha

BuriánEK D, HouzAR S, KRMíčEK L, ŠMERda J (2017) Origin of the pegmatite veins within the skarn body at Vevčice near Znojmo (Gföhl Unit, Moldanubian Zone). J Geosci 62: 1-23

Cathelineau M (1988) Cation site occupancy in chlorites and illites as a function of temperature. Clay Miner 23: 471-485

Černý P, Litochleb J, Šrein V (1995) Chrom-vanadové granáty z grafitového ložiska Domoradice u Českého Krumlova. Bull mineral-petrolog Odd Nár Muz (Praha) 3: 205-209

ČopJAKOVÁ R, ŠKodA R (2006) Detritické a autigenní REE minerály $v$ sedimentech kulmu Drahanské vrchoviny, jejich význam pro studium provenience klastického materiálu a procesů diagenese. Acta Mus Moraviae, Sci Geol 91: 105-127

Deer WA, Howie RA, Zussman J (1997) Rock-forming minerals, Vol. $1 A$ Orthosilicates. $2^{\text {nd }}$ ed. The Geological Society London

DoBEŠ P, MaLÝ K (2001) Mineralogie polymetalických rudních výskytů ve střední části havličkobrodského revíru. Vlast sborn Vysoč, odd prír věd 15: 51-85

DoležELOVÁ T (2015) Hydrotermální alterace vybraných typů hornin $v$ havlíčkobrodském rudním revíru (moldanubikum). MS, diplomová práce, UP Olomouc

DoLNiČEK Z, KROBOT J (2013) Žilná granát-kalcitová mineralizace $v$ kontaktně metamorfovaných pískovcích $\mathrm{z}$ Bučníku u Komni (bělokarpatská jednotka). Geol Výzk Mor Slez 20: 85-88

DolničEK Z, ULMANOVÁ J (2019) Mineralogická charakteristika dvou typů hydrotermálních žil s obsahem REE minerálů z lomu u Vrbčan (kutnohorské krystalinikum). Bull Mineral Petrolog 27: 331-345
Feneyrol J, Giuliani G, Ohnenstetter D, Fallick AE, Martelat Je, Monié P, Dubessy J, Rollion-Bard C, Le Goff E, Malisa E, Rakotondrazafy afM, Pardieu V, Kahn T, IChang'I D, Venance E, Voarintsoa NR, Ranatsenho MM, Simonet C, Omito E, Nyamal C, Saul M (2013) New aspects and perspectives on tsavorite deposits. Ore Geol Rev 53: 1-25

FILIP J, HouZAR S, SulovskÝ P (2002) Allanit a produkty jeho přeměny $z$ pegmatitu a ze skarnu u Rešic, západní Morava. Acta Mus Moraviae, Sci geol 87: 87101

FleEt ME (2003) Sheet silicates: Micas. Rock-forming minerals, Vol. $3 \mathrm{~A}, 2^{\text {nd }}$ ed. The Geological Society. London

Franz G, Liebscher A (2004) Physical and chemical properties of epidote minerals - an introduction. Rev Mineral Geochem 56: 1-82

GADAS P (2012) Studium systému granit-pegmatit z ofiolitů u Rudy nad Moravou. MS, disertační práce, MU Brno

Gadas P, Novák M, Cempírek J, Filip J, Vašinová Galiová M, GRoAt LA, VšIANSKÝ D (2014) Mineral assemblages, compositional variation and crystal structure of feruvitic tourmaline from contaminated anatectic pegmatite in Mirošov near Strážek, Moldanubian Zone, Czech Republic. Can Mineral 52: 285-301

Gadas P, Novák M, Talla D, Vašinová Galiová M (2013) Compositional evolution of grossular garnet from leucotonalitic pegmatite at Ruda nad Moravou, Czech Republic; a complex EMPA, LA-ICP-MS, IR and CL study. Miner Petrol 107: 311-326

Gieré R, Sorensen SS (2004) Allanite and other REE-rich epidote-group minerals. Rev Mineral Geochem 56: 431-493

Grew ES, Locock AJ, Mills SJ, Galuskina IO, Galuskin EV, HALENIUS U (2013) Nomenclature of the garnet supergroup. Am Mineral 98: 785-811

HAK J, JOHAN Z (1961) Mineralogicko-geochemický výzkum indiové anomálie Pohled u Havlíčkova Brodu. Sbor geol věd, technol geochem 2: 77-101

HaVLíčeK J, VÝRAVSKÝ J, MaLÝ K (2018) Nálezy zeolitů v lomu Pohled u Havlíčkova Brodu. Acta Rer Nat 22: 1-4

HouzAR S (1995) Grafitické kvarcity s vanad obsahujícími minerály v moravském moldanubiku. Geol Výzk Mor Slez v r 1994: 89-90

Hybler J, Sejkora J, Venclík V (2016) Polytypism of cronstedtite from Pohled, Czech Republic. Eur J Mineral 28: 765-775

KADLEC T (2018) Nález scheelitového zrudnění v kamenolomu Pohled u Havlíčkova Brodu. Minerál 24(6): 502-508

Kadlec T, Venclík V, Pauliš P (2018) Nález zeolitů a doprovodné mineralizace $z$ žil alpského typu a hydrotermálně alterovaných pegmatitů v kamenolomu Pohled u Havlíčkova Brodu. Minerál 24(5): 107-118

KOPECKÝ S, PAULIŠ P (2019) Nález krystalovaných scheelitů v kamenolomu Pohled u Havlíčkova Brodu. Minerál 27(6): 511-513

KROPÁČ K, BuRIÁNEK D, ZIMÁK J (2012) Origin and metamorphic evolution of Fe-Mn-rich garnetites (coticules) in the Desná Unit (Silesicum, NE Bohemian Massif). Chem Erde 72: 219-236 
Leake Be, Woolley AR, Arps Ches, Gilbert MCh, GriCE JD, haWthorne FC, Kato A, KIsch HJ, KrivovicheV VG, Linthout K, Laird J, Mandarino JA, Maresch WV, Nickel EH, ROCK NMS, Schumacher JC, SMITH DC, Stephenson NCN, UngaretTI L, ERIC JW, WhitTAKER EJW, YouzHI G (1997) Nomenclature of amphiboles: report of the Subcommittee on Amphiboles of the International Mineralogical Association, Commission on New Minerals and Mineral Names. Canad Mineral 35: 219-246

Lee SG, Lee DH, Kim Y, Chae BG, Kim WY, Woo NCh (2003) Rare earth elements as indicators of groundwater environment changes in a fractured rock system: evidence from fracture - filling calcite. Appl Geoch 18: 135-143

London D (2008) Pegmatites. Can Mineral, Special Publication 10, $347 p$

MAstíková E (2009) Geologická dokumentace lomu Pohled (moldanubikum). MS, bakalářská práce, UP Olomouc

MAstíková E (2011) Mineralogie a podmínky vzniku vybraných mineralizací v lomu Pohled (moldanubikum). MS, diplomová práce, PřF UP v Olomouci

McLenNAN SM (1989) Rare earth elements in sedimentary rocks: influence of provenance and sedimentary processes. Rev Mineral 21: 169-200

MELKA K (1965) Návrh na klasifikaci chloritových minerálů. Věst Ústř Úst geol 40: 23-27

Moupic Z, TošER Z (1985) Nález molybdenitového zrudnění na lokalitě Pohled u Havlíčkova Brodu. Čas Min Geol 30: 331-332

Mueller AG, Delor CP (1991) Goldmanite-rich garnet in skarn veins, Southern Cross greenstone belt, Yilgarn Block, Western Australia. Mineral Mag 55: 617-620

NĚMEC D (1963) Eruptivgesteine in westmährischen Skarnen und ihre genetische Stellung. N Jb Mineral, Abh 100: 203-224

NovÁK M (2005) Granitické pegmatity Českého masívu (Česká republika); mineralogická, geochemická a regionální klasifikace a geologický význam. Acta Mus Moraviae, Sci Geol 90: 3-75

NovÁK M, GADAS P (2010) Internal structure and mineralogy of a zoned anorthite- and grossular-bearing, leucotonalitic pegmatite in serpentinized Iherzolite at Ruda nad Moravou, Staré Město Unit, Czech Republic. Can Mineral 48: 535-556

Novák M, Kadlec T, GadAs P (2013) Geological position, mineral assemblages and contamination of granitic pegmatites in the Moldanubian Zone, Czech Republic; examples from the Vlastějovice region. J Geosci 58: 21-47

Pauliš P, Havlíček J., Kopecký S, Jebavá I (2012) Mimetit z kamenolomu Pohled u Havlíčkova Brodu (Česká republika). Acta Rer Nat 13(1): 1-3

Pauliš P, Hrưzek L, Janeček O, DVoŘák Z, Toman J (2015) Nejzajímavější mineralogická naleziště Čech - zeolity a doprovodná mineralizace. Kuttna, Kutná Hora

Pauliš P, Kopecký S, Jebavá I, Havlíček J (2013) Nové mineralogické nálezy z kamenolomu Pohled u Havlíčkova Brodu. Minerál 21(4): 317-322
Petrík I, Broska I, LiPKA J, Siman P (1995) Granitoid allanite-(Ce) substitution relations, redox conditions and REE distributions (on an example of I-type granitoids, Western Carpathians, Slovakia). Geol Carpath 46: 7994

Pouchou JL, PICHOIR F (1985) "PAP" ( $\varphi \rho Z)$ procedure for improved quantitative microanalysis. In: ARMSTRONG JT (ed.) Microbeam Analysis: 104-106. San Francisco Press, San Francisco

Prokop J, Losos Z, Čopjaková R, Karásek J (2013) Mineralogy and genesis of rock fragments with pegmatite texture from serpentinite eluvium at Nová Ves near Oslavany. Bull Mineral-Petrolog Odd Nár Muz 21(2): 210-222

Rieder M, Cavazzini G, D'yakonov YS, Kamenetskil VAF, Gottardi G, Guggenheim S, Koval' PV, Mueller G, Nelva AMR, Radoslovich EW, Robert JL, Sassi FP, Takeda H, WeISS Z, WONES DR (1998) Nomenclature of micas. Can Mineral 36: 905-912

SEIDLOVÁ V (2011) Mineralogická charakteristika molybdenitového výskytu z lomu Pohled u Havlíčkova Brodu. MS, bakalářská práce, MU Brno

SCHREIER M, Dolní̌EK Z, MAŠEK V (2013) Fluidní inkluze v grosuláru „plovoucích granátư“ z mramoru z Vápenné v plášti žulovského plutonu. Geol Výzk Mor Slez 20: 148-151

TUREK K (2006) Charakteristika ultrabazických uzavřenin $v$ horninách moldanubika na lokalitách Polnička a Pohled. MS, bakalářská práce, MU Brno

TUREK K (2008) Charakteristika ultrabazických uzavřenin $\checkmark$ horninách moldanubika. MS, diplomová práce, MU Brno

Uher P, KováčIK M, Kubiš M, Shtukenberg A, Ozdín D (2008) Metamorphic vanadian-chromian silicate mineralization in carbon-rich amphibole schists from the Malé Karpaty Mountains, Western Carpathians, Slovakia. Am Mineral 93: 63-73

UHER P, RUŽıČKA P, BILOHUŠČIN V (2015) Chrómom a vanádom obohatený grossulár zo skarnu Dubová v Malých Karpatoch (Slovensko). Bull Mineral-Petrolog Odd Nár Muz (Praha) 23(1): 19-25

Venclík V, Sejkora J, Škácha P, Pauliš P (2013) Vivianit z lomu Pohled u Havlíčkova Brodu (Česká republika). Bull Mineral-Petrolog Odd Nár Muz (Praha) 21(2): 191-194

Watanabe Y, Kon Y, Echigo T, Kamel A (2016) Differential fractionation of rare earth elements in oxidized and reduced granitic rocks: Implication for heavy rare earth enriched ion adsorption mineralization. Res Geol 67: 35-52

WeLser P, ZÁRUBA J (2004) Biotitický pegmatit s fluorapatitem od Pohledu u Havlíčkova Brodu. Bull Mineral-Petrolog Odd Nár Muz Praha 12: 216-219

WIeWIÓRA A, WeIss Z (1990) Crystallochemical classifications of phyllosilicates based on the unified system of projection of chemical composition: II. The chlorite group. Clay Miner 25: 83-92

Wood SA, RicketTs A (2000) Allanite-(Ce) from the Eocene Casto granite, Idaho: Response to hydrothermal alteration. Can Mineral 38(1): 81-100 